\title{
Clitic doubling in Peninsular and Rioplatense Spanish: a comparative corpus investigation* $^{*}$
}

\author{
Esther Rinke, Judith Wieprecht, Martin Elsig \\ Goethe University Frankfurt \\ Esther.Rinke@em.uni-frankfurt.de; J.Wieprecht@gmx.de; m.elsig@em.uni-frankfurt.de
}

Received: 25-03-2019

Accepted: 09-09-2019

\begin{abstract}
The current study compares the distribution of clitic doubling in two varieties of Spanish: Peninsular Spanish and Rioplatense Spanish. Comparing two corpora of colloquial speech, we investigate under which conditions clitic doubling with pronominal and nominal objects is possible and which factors favor the occurrence of doubling in variable contexts. This study adds new empirical evidence to the investigation of clitic doubling by providing a systematic comparative corpus study of the two different varieties of Spanish which is quantitatively extensive, methodologically sound (including the variable context of clitic doubling) and exclusively based on colloquial (vernacular) speech data. Based on a variationist analysis with Rbrul, our study confirms that the factors determining the distribution of clitic doubling (case marking, definiteness and differential object marking) can be ordered on an implicational (definiteness) scale and that doubling has a wider distribution and is less restricted in Rioplatense Spanish in comparison to Peninsular Spanish. We conclude that this reflects that Rioplatense Spanish has reached a more advanced stage of clitic doubling on a grammaticalization cline than Peninsular Spanish.
\end{abstract}

This work has been carried out as part of the research project 'Clitic Doubling across Romance' (GZ: RI 1953/2-1) funded by the German Science Foundation (DFG). 
Keywords: Rioplatense Spanish; Peninsular Spanish; clitic doubling; corpus-based analysis; definiteness scale.

\section{Table of Contents}

\section{Introduction}

2. Background: Features involved in $\mathrm{CD}$ 3. Corpus and methodology

\section{Results and discussion}

5. Summary and conclusion References

\section{Introduction}

This paper compares the distribution of clitic doubling (CD) in two varieties of Spanish: Peninsular and Rioplatense Spanish. More precisely, we compare colloquial speech data of the Madrid region and from Buenos Aires (C-ORALROM-Corpus (Cresti \& Moneglia, 2005), COLA corpus (Jørgensen, 2008), see section 3) with respect to doubling of different types of pronominal and nominal objects $^{1}$ by clitic pronouns. The overall aim of this study is to disentangle the different factors that determine the variable use of CD in these varieties and to find out whether the differences between them can be accounted for in terms of an extension along a systematic and predictable diachronic pathway.

$\mathrm{CD}$ refers to the use of a clitic pronoun and a co-referential pronoun or noun phrase in canonical object position as shown in (1). In example 1, both the clitic (le) and the nominal object (Juan) are contained within one and the same prosodic (ip, cf. 1a) and syntactic ( $v P, \mathrm{cf} .1 \mathrm{~b})$ unit. The nominal object is interpreted as new information focus or part of the focus domain (cf. (1c)) (cf. Gabriel and Rinke 2010: 65ff., see also Fernández Soriano, 1999; Estigarribia 2005, 2006; Zdrojewski 2008; Sanchez and Zdrojewski 2013, and references therein).

1 In the present paper, we use the terms pronominal and nominal objects in order to distinguish between pronouns and non-pronominal noun phrases in object position, although it is clear that pronouns are also nominal objects. We also use the abbreviation DP (Determiner Phrase) to refer to non-pronominal noun phrases. 


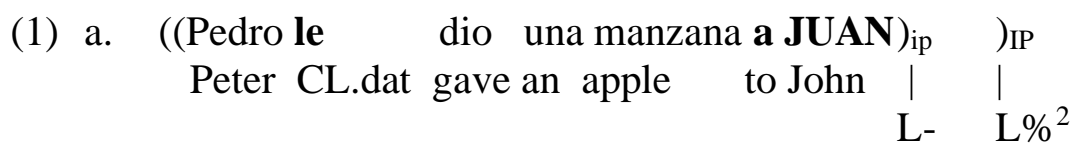

b. Pedro le dio T [ vp die una manzana die a Juan]

c. ('To whom did Peter give an apple?' / 'What did Peter do?' /

'What happened?')

Pedro le dio una manzana [F a JUAN]

Pedro [F le dio una manzana a JUAN]

[F Pedro le dio una manzana a JUAN]

'Peter gave an apple to John.' ${ }^{3}$

CD has to be distinguished from clitic left (CLLD) and right dislocation structures (CLRD). Dislocation structures also involve a resumptive clitic and a nominal object (2). However, in CLRD structures, the nominal object is not contained within the same prosodic and syntactic unit, but in a separate ip (cf. (2a)) and $v P$ (cf. (2b)). With respect to information structure, the dislocated object is interpreted as a topic (2c) (Gabriel and Rinke 2010: 65ff.).

(2) Clitic right dislocation (CLRD):

a. (( Pedro le dio una manZAna, ) ip (a Juan) $)_{\text {ip })}$ IP

b. Pedro le dio T [ $\mathrm{vP}_{\mathrm{p}}$ diø una manzana diø $\left.\mathrm{pro}_{\mathrm{i}}\right]^{4}$, a Juan

c. ('What did Peter give to John?')

Pedro le dio una manZAna, [topic a Juan]

'Peter gave him an apple, to John.'

$\mathrm{CD}$ is a variable phenomenon both within and across different varieties of Spanish. According to previous literature, doubling of stressed personal pronouns is mandatory in all varieties (cf. Fernández Soriano, 1999), as illustrated in (3a) and $(3 b)^{5}$. With indirect nominal objects (3c), CD represents the preferred option (cf. Fernández Soriano, 1999).

2 The notation of prosodic contours follows the conventions of the AutosegmentalMetrical (AM) framework (cf. Hualde 2003). As in Gabriel and Rinke (2010), we assume an intermediate phrasal (i.e. 'small' ip) boundary triggered by the insertion of a low intermediate boundary tone (L-) at the left edge of the right-dislocated material (cf. Astruc 2005). See Gabriel (2007: chap. 3.1.3.2) concerning the insertion of a high intermediate boundary tone (H-) at the right edge of a leftdislocated constituent.

3 Cf. Zubizaretta (1999) concerning the definition of the information structural notions of topic and focus used here and their realization in Spanish.

Concerning the analysis of CD as agreement marking, see Di Tullio (2005). DOM stands for Differential Object Marking (Bossong, 1985; Aissen, 2003), i.e. the marking of an animate and definite direct object by the preposition $a$. We come back to the notion of DOM and its relevance for CD in section 2.3.1. 
$\begin{array}{lllll}\text { (3) a. Le di el regalo a él. / * Di el regalo a él. } & \text { (IO-Pron) } \\ \text { CL.dat gave the present to him } & \end{array}$

'(I) gave him the present.'
b. Los
vi a
ellos. / *Vi a ellos.
(DO-Pron)
CL.acc
saw DOM
them
'(I) saw them.'
(Fernández Soriano, 1999:1248)
c. Le di el regalo a Juan./ ?Di el regalo a Juan.
CL.dat gave the present to Juan
'(I) gave the present to Juan.'
(IO-DP)

$\mathrm{CD}$ of nominal direct objects is considered to be ungrammatical in Peninsular Spanish. However, it is reported to occur in Rioplatense Spanish (cf. Jaeggli, 1982; Suñer, 1988; Parodi, 1998; Di Tullio and Zdrojewski, 2006; Zdrojewski, 2008; among others). ${ }^{6}$

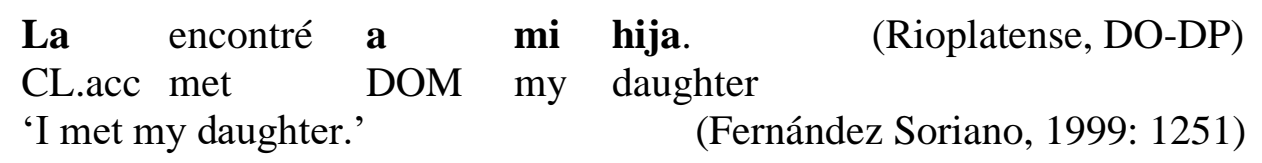

While it is undisputed that pronominal vs. non-pronominal objects and accusative vs. dative nominal objects differ with respect to $C D$ in all varieties of Spanish, a number of different factors have been proposed to account for CD of direct objects in Rioplatense Spanish: the presence of DOM (Jaeggli, 1982), specificity (Suñer, 1988), definiteness (Leonetti, 2007a), the interplay of animacy, specificity and definiteness (Parodi, 1998; Sánchez \& Zdrojewski, 2013), and the discourse status of the object (Belloro, 2007). In fact, all these factors seem to be relevant to some extent and they interact in a way that is not yet fully understood, especially if one wishes to account for the differences between the two varieties. The discrepancies between the different proposals may be due to the fact that previous studies focused on different factors and that they are based on very different types of empirical evidence. Some early studies (e.g. Jaeggli, 1982; Parodi, 1998) make use of introspective judgment data. The experimental study in Sánchez \& Zdrojewski (2013) focuses on the Spanish in Buenos Aires and Lima and does not include speakers from Peninsular Spanish. Although there are also many studies based on corpus data (e.g. Silva-Corvalán, 1984; Suñer, 1988; Koch, 1993; García-Miguel and Vázquez, 1994; Becerra Bascuñán, 2006; Estigarribia, 2006; Belloro, 2007; Dufter and Stark, 2008), there does not exist (to our knowledge) a systematic comparative corpus study of the two different varieties of Spanish which is quantitatively extensive, methodologically sound (including the variable context of $\mathrm{CD}$, see section 3.2) and exclusively based on colloquial

$6 \quad$ Accusative doubling has also been reported to be possible under certain conditions in other Latin American varieties of Spanish (Mayer, 2006; Sánchez \& Zdrojewski, 2013; among others) and in Basque Spanish (Ormazabal and Romero, 2013). 
(vernacular) speech data. ${ }^{7}$ A corpus of vernacular speech data is especially indispensable for such an investigation because $\mathrm{CD}$ of direct nominal objects in Rioplatense Spanish is indeed a feature of the spoken and colloquial register. In our study, we compare two vernacular corpora by applying the same methodology of data analysis and the same statistical methodology to them (C-ORAL-ROM-Corpus (Cresti \& Moneglia, 2005), COLA corpus (Jørgensen, 2008), see section 3).

A number of authors have proposed that the extension of CD to direct nominal objects in Rioplatense Spanish reflects an advancement in the diachronic development of CD (Leonetti, 2007a; Gabriel and Rinke, 2010; Sánchez and Zdrojewski, 2013; Pujalte and Saab, 2018; Di Tullio, Saab and Zdrojewski, 2019). Leonetti (2007a:135) proposes that this advancement follows the definiteness scale in (5).

Definiteness Scale:

$\varnothing<$ weak (clitic) pronouns $<$ strong (stressed) pronouns $<$ demonstratives

$<$ simple definite descriptions $<$ complex definite descriptions $<$

specific indefinites $<$ non-specific indefinites

(Leonetti, 2007a:135, our translation)

The Matching Principle, which requires the clitic to match the features of the doubled form (cf. Suñer, 1988), explains why CD starts out with strong pronouns, which match with clitics concerning the features (+pronominal, + definite, + specific). Extension across the definiteness scale implies that former restrictions are lost. Hence, as grammaticalization of the clitic proceeds, CD may extend into contexts in which features like definiteness and specificity are not necessarily given any longer. The definiteness scale can be understood as an implicational hierarchy, both diachronically and synchronically: diachronically because the emergence of CD with pronouns historically precedes that with full lexical nouns, and synchronically because only forms of CD that are indicative of later stages on the grammaticalization pathway may coexist with earlier ones.

In accordance with these observations and with the proposals by Leonetti (2007a) and Sánchez \& Zdrojewski (2013), Fischer and Rinke (2013) argue that the diachronic evolution of $\mathrm{CD}$ includes two aspects: first, a catastrophic or macroparametric change, namely the emergence of clitics in a language and, second, the spread of doubling to different contexts following an implicational scale based on the definiteness scale proposed by Leonetti (2007a, 2008; cf. ex. 5). They propose the following parameter hierarchy including one macroparameter (emergence of a category of $\mathrm{D}^{\circ} /$ phi-clitics) followed by potential but strictly ordered microparametric changes (steps that languages may follow; changes concerning a property within one and the same category) to account for the implications.

$7 \quad$ Some studies (e.g. Suñer, 1988; Belloro, 2007; Di Tullio et al., 2019) are based on the corpus El Habla Culta de la Ciudad de Buenos Aires (Barrenechea 1987). This corpus varies in both the number of interlocutors and the level of formality, ranging from a university lecture to the informal dialogue [...] (Belloro 2007: 72). 
Figure 1: Parameter hierarchy proposed by Fischer and Rinke (2013: 468)

Parameter hierarchy building on Baker (2008: 3), (see also Roberts 2011)

$\mathrm{Cl}($ itic) pronouns

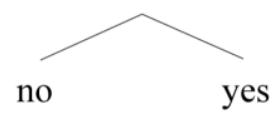

$\mathrm{Cl}$ doubling of full pronouns

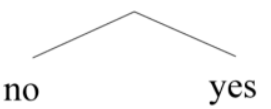

$\mathrm{Cl}$ doubling of dative nominal objects

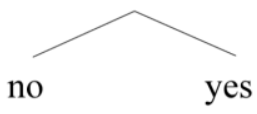

$\mathrm{Cl}$ doubl. of specific accusative nominal objects

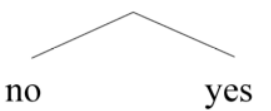

$\mathrm{Cl}$ doubl. of accusative nominal objects

In view of the implicational nature of the hierarchy, it is not expected that any variety of Spanish will allow for the existence of later stages, e.g. CD of accusative nominal objects, while at the same time precluding that of earlier ones, e.g. $\mathrm{CD}$ of dative nominal objects or pronouns.

A study investigating the spread of CD in Peninsular Spanish by Gabriel and Rinke (2010) has indeed shown that, diachronically, the extension of CD in the Spanish grammar proceeds in different steps: in the $15^{\text {th }}$ century, personal pronouns start to be doubled ( $20 \%$ CD vs. $80 \%$ no CD), whereas indirect object DPs still occur without a coreferential clitic pronoun in the same sentence. In the $16^{\text {th }}$ century, systematic CD of personal pronouns is established $(80 \%$ CD vs. $20 \%$ no CD), doubling of indirect object DPs increases and reaches $20 \%$ in the $18^{\text {th }}$ century (cf. table 1, figure 2). Doubling of direct nominal objects is not attested in the historical corpus. 
Table 1: Distribution of strong pronominal (direct and indirect) objects, indirect full nominal objects and experiencer arguments with and without a clitic $\left(15^{\text {th }}\right.$ - 18 ${ }^{\text {th }}$ centuries), apud Gabriel and Rinke (2010)

\begin{tabular}{|c|c|c|c|c|c|c|}
\hline century & \multicolumn{4}{|c|}{ pronominal objects } & \multicolumn{4}{|c|}{ indirect full nominal objects } \\
\hline & All & + CD & - CD & all & +CD & -CD \\
\hline $\mathbf{1 5}^{\text {th }}$ & 42 & 7 & 35 & 105 & 1 & 104 \\
\hline & $100 \%$ & $17 \%$ & $83 \%$ & $100 \%$ & $1 \%$ & $99 \%$ \\
\hline $\mathbf{1 6}^{\text {th }}$ & 14 & 11 & 3 & 40 & 4 & 36 \\
\hline & $100 \%$ & $79 \%$ & $21 \%$ & $100 \%$ & $10 \%$ & $90 \%$ \\
\hline $\mathbf{1 7}^{\text {th }}$ & 38 & 27 & 11 & 62 & 13 & 49 \\
\hline & $100 \%$ & $71 \%$ & $29 \%$ & $100 \%$ & $21 \%$ & $79 \%$ \\
\hline $\mathbf{1 8}^{\text {th }}$ & 80 & 71 & 9 & 62 & 11 & 51 \\
\hline & $100 \%$ & $89 \%$ & $11 \%$ & $100 \%$ & $18 \%$ & $82 \%$ \\
\hline
\end{tabular}

Figure 2: Diachronic development of CD with pronominal and indirect nominal objects (Gabriel and Rinke 2010)

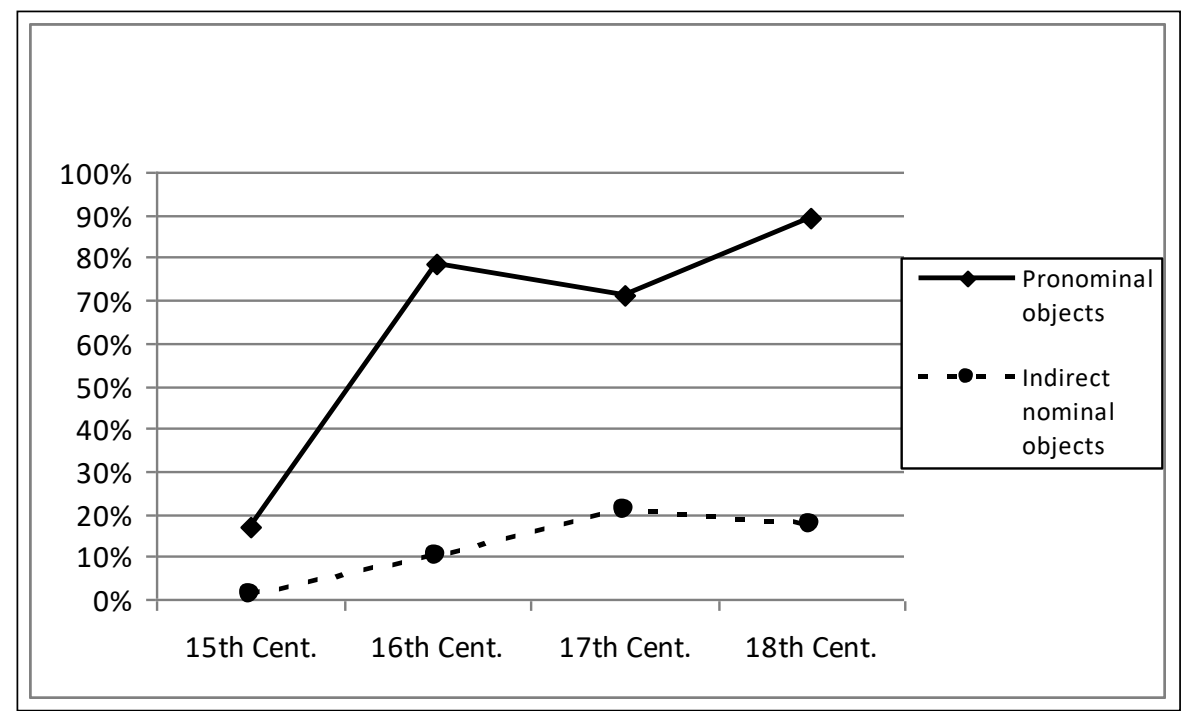

Although we report diachronic evidence to illustrate how diachronic and synchronic variation may interact, our study is not a diachronic investigation and we are aware of the fact that written texts cannot easily be compared to spoken and colloquial speech data. However, diaphasic and diachronic variation are not independent from each other. We predict that both synchronic and diachronic 
variation of $\mathrm{CD}$ are determined by the hierarchies sketched above. We expect that - independent of the medium - later stages of development always include the earlier ones but not the other way around.

A similar conclusion is reached in recent work by Di Tullio et al. (2019). The authors assume that $\mathrm{CD}$ is triggered by a person feature in pronouns/lexical DPs. They account for the dialectal variation between Argentinian Spanish and other Spanish dialects with respect to the doubling of direct object DPs by assuming that lexical DPs in Argentinian Spanish can be optionally assigned a [3rd person] feature whereas this is not possible in other dialects of Spanish. Following this analysis, the synchronic and diachronic variation can be accounted for by assuming that $\mathrm{CD}$ reflects a gradual process of grammaticalization of the person feature on the $\mathrm{D}^{\circ}$ head of the object (cf. Pujalte and Saab 2018). Following this analysis and in accordance with the conclusions reached by Gabriel and Rinke (2010), Argentinian Spanish reflects a diachronic extension of CD in comparison to other dialects of Spanish.

The aim of this paper is twofold: first, based on a systematic comparative quantitative and qualitative corpus analysis, we want to enrich the empirical evidence in order to understand how the different abovementioned factors contribute to the variation of CD within and across the two varieties of Spanish under investigation. Second, on the basis of our results, we want to discuss the question whether the proposed implicational hierarchy can be confirmed.

The paper is organized as follows: Section 2 presents and discusses in more detail the factors that have been proposed in the literature to account for the variability of $C D$. On the basis of this discussion, we will derive more elaborated research questions and hypotheses for our corpus study. Section 3 gives an overview of the corpora and the methodology. In section 4, we present the quantitative results and discuss the distribution of $\mathrm{CD}$ on the basis of examples from the two corpora. In section 5, we come back to our initial research questions and hypotheses, summarize and conclude.

\section{Background: Features involved in CD}

As already mentioned above, grammatical factors such as the syntactic category (pronominal vs. non-pronominal), case (accusative vs. dative) and the presence or absence of DOM have been discussed (Kayne, 1975; Fontana, 1993; Fernández Soriano, 1999; Anagnostopoulou, 2003; Leonetti, 2007a, 2008; Heusinger \& Onea, 2008; Zdrojewski 2008; Saab and Zdrojewski 2012, 2013; Di Tullio et al., 2019). In addition, semantic and pragmatic factors like specificity (Suñer, 1988; Enç, 1991; Gerlach, 2002), definiteness (Leonetti, 2007a, 2008), animacy (Suñer, 1988; Colantoni, 2002), or a combination of them (Parodi, 1998) have been suggested to be influential for CD as well as discourse factors like e.g. givenness (Chafe, 1987, 1994; Belloro, 2007). 


\subsection{Pronominal and non-pronominal objects}

As already mentioned in the introduction and illustrated in (3), CD is mandatory with personal pronouns in all varieties of Spanish (Fernández Soriano, 1999: 1248) and diachronically, personal pronouns are the first to be doubled in Spanish (Fontana, 1993; Company Company, 2003; Kuchenbrandt, 2009; Gabriel and Rinke, 2010; cf. figure 2). However, not all pronominal elements are always doubled. The pronoun usted, which is a polite form of address for the $2^{\text {nd }}$ person but morphologically selects $3^{\text {rd }}$ person agreement, is optionally doubled by a clitic pronoun (cf. 6a). The $3^{\text {rd }}$ person neutral pronoun ello is generally not doubled (6b), although this is possible in some contexts (cf. Fernández Soriano 1999: 1248).
(6) a. Agradezco a usted. / Le agradezco a usted.
thank to you / CL.dat thank to you
'I thank you.' (Fernández Soriano, 1999:1248; Poston, 1953)
b. Dedicaré a ello el siguiente capítulo.
dedicate.FUT to this the following chapter
'I will dedicate the following chapter to this.

(Fernández Soriano, 1999:1248)

\subsection{Case}

Doubling of indirect objects is frequent and occurs in all varieties of Spanish. The same is not true for CD of accusative direct objects which is considered to be a typical feature of Rioplatense Spanish ${ }^{8}$ but not of Peninsular Spanish. The dativeaccusative case asymmetry, that has already been illustrated in examples (3) and (4) above, has led to a defragmented analysis of accusative and dative clitics. Several authors have proposed that accusative clitics are determiners (D-elements) whereas dative clitics have been reduced to $\varphi$-features and function as agreement markers (cf. Anagnostopoulou, 2003; Bleam, 2000; Déchaine \& Wiltschko, 2002; Ormazabal and Romero, 2013; Torrego, 1988; Uriagereka, 1988 for proposals along these lines). These proposals explain the case asymmetry, but in some respects, they seem too powerful. For instance, it is not clear how they account for the optionality of doubling of indirect nominal objects and for the categorical doubling of strong accusative pronouns. It is also unclear what the implications are for varieties like Rioplatense Spanish, where CD of accusative nominal objects is a grammatical option but occurs only under certain conditions. In the next subsection, we present the factors that have been proposed to account for the variability of $\mathrm{CD}$ with accusative nominal objects.

\subsection{Factors determining doubling of direct nominal objects}

\subsubsection{DOM}

$8 \quad$ Based on the study in Barrenechea \& Orecchia (1970/71), Koch (1993) reports $100 \% \mathrm{CD}$ with strong personal pronouns, $41.8 \% \mathrm{CD}$ with indirect objects (among all realizations of indirect objects, preposed indirect objects included) and $0.8 \%$ of CD with [-human] direct objects and $7.9 \%$ of [+human] direct object DPs in Rioplatense Spanish. 
Jaeggli (1982) observes a correlation between the possibility of doubling of direct nominal objects and the occurrence of DOM. Referring to Kayne (1975), Jaeggli (1982) assumes that the preposition $a$ functions as a case marker. Because the finite verb does not have to case mark the nominal (or pronominal) object in canonical object position, the occurrence of an additional object, the pronominal clitic, is licensed (Kayne`s generalization (apud Jaeggli, 1982)). According to Jaeggli (1982), animacy is not necessarily involved, as DOM can mark inanimate objects as well (7).

$$
\begin{aligned}
& \text { Los ácidos atacan a los metales. } \\
& \text { the acids attack DOM the metals } \\
& \text { 'Acids attack metals.' }
\end{aligned}
$$

Although it is undisputed that clitic doubled direct objects usually show DOM marking, Suñer (1988) argues on the basis of the examples in (8a-b) that the occurrence of DOM is not a necessary condition for CD to occur.

(8) a. Yo la tenía prevista esta muerte. (Suñer, 1988:399)

(RSp.)

I CL.acc had anticipated this death

'I have anticipated this death.'

b. Lo último que escuché, claro que la encontré (R.Sp.) the last that heard clearly that CL.acc found pesada la audición, fue el reportaje (...) a Jorge Luis Borges. heavy the audition was the report to Jorge Luis Borges 'The last thing that I heard - it is clear that I found the audition boring was the report about Jorge Luis Borges.'

(Barrenechea y Orecchia, 1977:368)

This view has been challenged in more recent studies (cf. Zdrojewski, 2008; Saab and Zdrojewski, 2012, 2013; Di Tullio et al., 2019), which argue that examples like (8a-b) are cases of CLRD, because the DP object cannot be analyzed as being focused or part of the focus domain. Among other arguments, the authors claim, that in examples like (8a-b), the main stress falls on the constituent preceding the object and the direct object undergoes deaccentuation (cf. Di Tullio et al., 2019). In addition, it is argued that clitic-doubled inanimate DP objects are infelicitous in contexts where the object is focused (e.g. as an answer to a question as in (9) and preceded by a focal adverb like solo 'only' (10)).

(9) Question: Vos, ¿qué vas a comprar antes de subir? you what go to buy before of coming-up

'What will you buy before you come up?'

Answer: Yo (\#lo) voy a comprarel diario [CLRD]

I CL.acc go to buy the newspaper

antes de subir.

before of coming - up

'I am going to buy it, the newspaper, just before coming up.'

(Di Tullio et al. 2019: 222) 

(10)a. *Juan lo trajo, solo [el LIBRO]F. [CLRD] Juan CL.acc bring only the book
b. Juan trajo solo [el LIBRO $]_{\mathrm{F}}$. Juan bring only the book 'Juan brought only the book.'

(Di Tullio et al. 2019: 223)

Based on the assumption that the examples in (8a-b) have to be analyzed as instances of right-dislocation, the studies mentioned above conclude that in configurations with inanimate DPs and without DOM, CD is not licensed and that Kayne's generalization holds because DOM marking is indeed a necessary condition for CD to occur.

\subsubsection{Specificity, definiteness and animacy}

Several authors have proposed that semantic features of the object are relevant for the occurrence of CD with direct nominal objects. Suñer (1988) proposes that specificity is the relevant feature conditioning direct object CD in Rioplatense Spanish. She assumes that the clitic and the noun phrase form a chain and match in their features (Matching principle). Yet, Leonetti (2007b) calls this view into question and shows that clitics allow for non-specific readings (11a.-b.).

(11)a. Cuando te encuentras en una situación así, when yourself find in a situation like.this, es difícil manejarla. is difficult manage.CL.acc

'When you find yourself in a situation like this, it is difficult to manage it.'

b. Aquí podemos coger un taxi sin tener que llamarlo.

here we.can take a taxi without have to call.CL.acc

'Here we can take a taxi without having to call one.' (Leonetti, 2007b)

The examples show that clitic pronouns do not include an inherent feature for specificity. According to Leonetti (2007a), apparent effects of specificity are not the result of such a semantic feature but the linguistic marking of definiteness in conjunction with the interpretation in context. He concludes that the relevant feature that conditions direct object $\mathrm{CD}$ is therefore definiteness instead of specificity.

Parodi (1998) argues that specificity and definiteness alone are not sufficient to guarantee direct object CD in Rioplatense Spanish. In her view, only the combination of specificity, definiteness and animacy (cf. for animacy also 
Colantoni, 2002) in the direct nominal object allows that it can be clitic-doubled (ex. 12).

(12)a. (+def., -spec., +animate)

*La busco a la mujer que sepa inglés.

CL.acc I.look for DOM the woman that know.SUBJ English.

b. (-def., +spec., +animate)

*La veo a una mujer.

CL.acc I.see DOM a woman

c. (+def., +spec., +animate)

La veo a la mujer.

CL.acc I.see DOM the woman

'I see the woman.' (Parodi, 1998:88)

\subsection{Research questions and hypotheses}

Our first research question relates to the syntactic category of the object in canonical object position:

1. To what extent is the feature [+/- pronominal] involved in CD? In which way does this feature interact with other features and what triggers doubling with non-personal pronouns?

As mentioned above, we expect that personal pronouns are virtually always doubled by a clitic pronoun in both varieties. With respect to other types of pronouns, it is not clear to which extent they are also systematically or preferentially doubled and which factors favor the occurrence of doubling. Our second research question concerns the case asymmetry:

\section{To what extent does case determine CD?}

We expect that the case asymmetry between dative and accusative objects is valid in both varieties of Spanish and that dative objects are preferentially doubled in Peninsular as well as in Rioplatense Spanish. Since doubling of indirect objects is in principle optional, the two dialects may nevertheless differ with respect to the overall frequency of doubling with indirect objects or with respect to the factors that favor its occurrence.

Our third research question is:

3. What is the relation between CD of direct objects and DOM in the corpora and what is the role of semantic factors (definiteness, specificity, animacy)?

Regarding CD of direct nominal objects, we expect that this structure is not attested (or severely restricted) in Peninsular Spanish but systematically found in Rioplatense Spanish. We also expect DOM and semantic factors to be involved in the CD of direct objects although it may be difficult to see to which extent each single factor is relevant and how the different factors interact. 
Our fourth research question relates to the comparison between the two varieties and to the implicational scale presented in the introduction.

4. What are the commonalities and what are the differences between the two varieties of Spanish? Can intra- and inter-dialectal variability of $C D$ be accounted for by an implicational hierarchy which is based on the definiteness scale presented in (5)?

As already mentioned, we expect Peninsular Spanish and Rioplatense Spanish to show similar results concerning the doubling of pronominal and indirect nominal objects but differences concerning direct nominal objects. If the implicational hierarchy proposed above correctly predicts the variability of doubling, we expect $\mathrm{CD}$ to occur with objects on the right edge of the scale only if it also occurs with elements to its left.

\section{Corpus and methodology}

Our data base consists of data from different corpora of spontaneous speech. We included data from Spain (mainly Madrid) and Argentina (Buenos Aires), which were taken from three different electronically available corpora: a) the COLA corpus Madrid \& Buenos Aires (Corpus Oral de Lenguaje Adolescente, www.colam.org, Annette Myre Jørgensen and Esperanza Eguía Padilla, cf. Jørgensen, 2008) and b) parts of the C-ORAL-ROM-Corpus (Cresti and Moneglia 2005) for Madrid. The data were coded according to the same methodology and finally underwent a statistical analysis with Rbrul (Johnson, 2009). In the following sub-sections, we provide more detailed information about our data base, the methodology of data coding and the statistical analysis.

\subsection{Description of the corpus and methodology}

The COLA corpus (Jørgensen, 2008) contains adolescent speech of 13- to 19-yearold teenagers. It includes samples of spontaneous and vernacular speech, recorded in the schoolyard. 2663 tokens from the Madrid part of the corpus have been extracted and coded for the present study and 2303 tokens from the Buenos Aires part.

The C-ORAL-ROM-Corpus (Cresti \& Moneglia, 2005) also includes samples of spontaneous speech. In order to use comparable data to the COLA corpus, we selected recordings in informal situations which were qualified in the corpus as 'family/private'. The speakers mainly stem from Madrid and some from Segovia. $80 \%$ of the speakers are in between 18 and 40 years of age. 2005 tokens have been extracted from this corpus.

\subsection{Methodology}

It is crucial to mention that in our treatment of the data, we focused on the variable context in which the phenomenon of CD occurs. We made use of an insight of Variationist Sociolinguistics, namely that describing the distribution of a 
phenomenon implies to consider its "envelope of variation" (Labov, 1972). This means that one has to take into account all the actual occurrences of the phenomenon but also "all those cases where the form might have occurred but did not" (Tagliamonte, 2006: 86). In order to take into account the variable context of $\mathrm{CD}$, we extracted all sentences featuring a direct and/or indirect object and coded it for the present study.

Since our focus is on objects in canonical object position (see section 1), we excluded cases of clitic left dislocation (CLLD) (COLA Madrid N=115, C-OralRom $\mathrm{N}=110$, COLA Buenos Aires $\mathrm{N}=80$ ) and clitic right dislocation (CLRD) (COLA Madrid $\mathrm{N}=3$, C-Oral-Rom $\mathrm{N}=24$, COLA Buenos Aires $\mathrm{N}=0$ ) and dislocations without a resumptive clitic (Left dislocation: COLA Madrid N=26, COral-Rom $\mathrm{N}=29$, COLA Buenos Aires $\mathrm{N}=31$; Right dislocation: COLA Madrid $\mathrm{N}=0$, C-Oral-Rom N=4, COLA Buenos Aires $\mathrm{N}=3$ ). Dislocations were excluded from the analysis because they are structurally different from $\mathrm{CD}$ structures as explained in section 1.

In our corpora, dislocations are either marked by an intercalation of another constituent in between the verb and the object or by a prosodic break $(/, / / \$)$. Example (13) provides a case in point:

$$
\begin{aligned}
& {[<]<\text { me lo }[/] \mathrm{me} \text { lo }>\text { he comprado hoy }} \\
& \text { me CL.acc me CL.acc I.have bought today } \\
& / / \$<\text { el libro> }+\$ \\
& / / \$ \text { the book } \\
& \text { 'I have bought it today, the book.' (C-Oral-Rom: EFAMDL11) }
\end{aligned}
$$

We also excluded quirky subjects or structures behaving like quirky subjects (COLA Madrid N=100, C-Oral-Rom N=96, COLA Buenos Aires N=35) because they categorically require the presence of a clitic and are therefore not part of the variable context. This is exemplified by (14) below which would be ungrammatical without the clitic $l e$.

$$
\begin{aligned}
& \text { y es que le había pasado a otro hombre también //\$ } \\
& \text { And is that CL.dat had happened to other man too } \\
& \text { 'And it had happened to another man, too.' (C-Oral-Rom: EFAMDL22) }
\end{aligned}
$$

Since there were no significant differences between the two corpora of Madrid they were pooled together for the statistical analysis. For the comparative statistical analysis, we included 4161 tokens for Peninsular Spanish from the COral-Rom Madrid \& the COLA Madrid corpus and 2153 tokens for Rioplatense Spanish after having eliminated the potential cases of dislocation and quirky subjects.

All sentences including objects in canonical object position were coded with respect to the following features: $+/$ - doubling, + /- pronominal, $+/-$ animate, $+/-$ definite, $+/-$ specific, person, number, negation, DOM, and case. In addition, the following potentially favoring factors which have not been discussed in the literature were coded: number, null subjects, negative/affirmative polarity, sentential/non-sentential object, main/subordinated clause and finite/infinite clause. 
The data underwent a statistical analysis with Rbrul (Johnson, 2009) with doubling vs. non-doubling as the dependent variable and the various grammatical and semantic features that have been coded as independent variables.

\section{Results and discussion}

\subsection{Pronominal contexts}

In this section, we present the results obtained for $\mathrm{CD}$ of pronominal objects in the Madrid and in the Buenos Aires subcorpora. We first present the quantitative results and then discuss some of the examples in a more detailed way. By presenting the quantitative results, we first compare pronominal objects to nominal objects, second contrast personal pronouns to other types of pronouns (e.g. interrogative, relative, indefinite or quantificational pronouns) and third consider the different factors influencing $\mathrm{CD}$ with non-personal pronouns.

Table 2 shows the proportion of doubling with pronouns (including personal and non-personal pronouns) and noun phrases in the Peninsular Spanish (Madrid) corpus and in the Rioplatense Spanish (Buenos Aires) corpus.

Table 2: Proportion of doubling with pronouns and noun phrases in COLA $+C$ Oral-Rom Madrid and in COLA Buenos Aires (including personal and nonpersonal pronouns)

\begin{tabular}{|c|c|c|c|c|c|}
\hline & & \multicolumn{2}{|c|}{$\begin{array}{c}\text { COLA }+ \text { C-Oral-Rom } \\
\text { Madrid }\end{array}$} & \multicolumn{2}{|c|}{ COLA Buenos Aires } \\
\hline & & $\mathbf{N}$ & $\%$ & $\mathbf{N}$ & $\%$ \\
\hline \multirow{4}{*}{$\begin{array}{l}\text { pronominal } \\
\text { objects }\end{array}$} & doubling & 100 & 10.8 & 73 & 10.2 \\
\hline & $\begin{array}{l}\text { non- } \\
\text { doubling }\end{array}$ & 828 & 89.2 & 645 & 89.8 \\
\hline & $\Sigma$ & 928 & 100 & 718 & 100 \\
\hline & doubling & 107 & 3.3 & 123 & 8.6 \\
\hline
\end{tabular}




\begin{tabular}{|c|c|c|c|c|c|}
\hline $\begin{array}{l}\text { nominal } \\
\text { objects }\end{array}$ & $\begin{array}{l}\text { non- } \\
\text { doubling }\end{array}$ & 3126 & 96.7 & 1312 & 91.4 \\
\hline & $\Sigma$ & 3233 & 100 & 1435 & 100 \\
\hline
\end{tabular}

A Chi-Square test shows that, in Peninsular Spanish, the difference between pronominal and non-pronominal contexts regarding $\mathrm{CD}$ is statistically significant $\left(x^{2}=85.0254 ; \mathrm{p}<0.001\right)$. Due to the overall higher proportion of CD with nominal objects in Rioplatense Spanish, this difference is not significant in this variety $\left(x^{2}=1.4726 ; p=0.22494\right)$.

Tables 3 provides the numbers and proportions of doubling with personal pronouns vs. other pronouns in Madrid and Buenos Aires.

Table 3: Proportion of doubling with personal pronouns vs. other pronouns in COLA + C-Oral-Rom Madrid and in Cola Buenos Aires

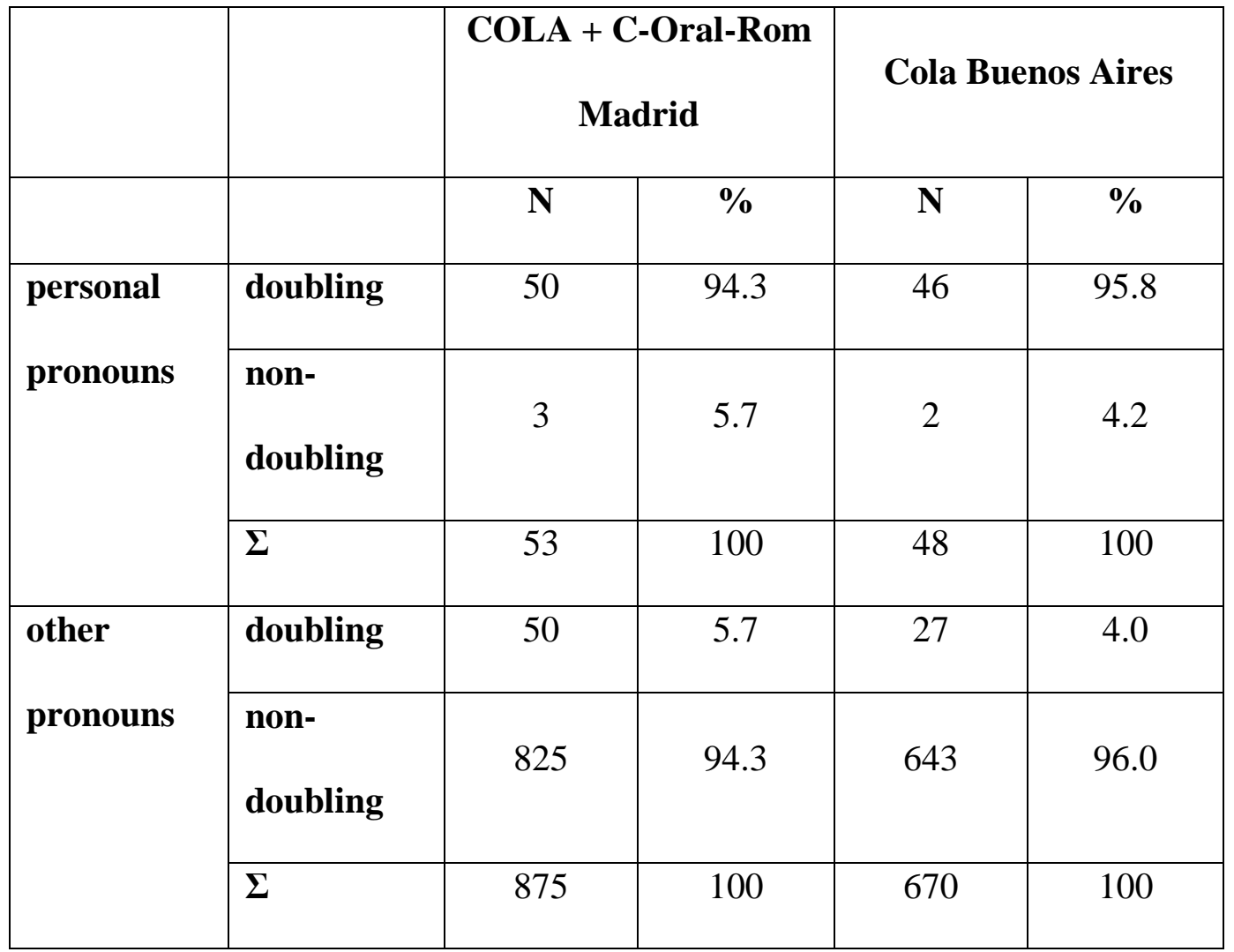

Both in Peninsular Spanish $\left(x^{2}=408.2417, \mathrm{p}<0.001\right.$ (highly significant)) and in Rioplatense Spanish $\left(\chi^{2}=413.3103, \mathrm{p}<0.001\right.$ (highly significant)) personal 
pronouns are doubled almost categorically and doubling is significantly more likely with personal (15a) than other types of pronouns (e.g. interrogative, relative, indefinite or quantificational pronouns). Only 5.7\% (Madrid) and $4.0 \%$ (Buenos Aires) of non-personal pronouns are doubled (15b).

(15)a. y me estaban mirando a mí and CL.acc they.were looking DOM me 'And they were looking at me.' (COLA Madrid: MABPE2-02)

b. es que claro/ el centro/ se lo paga todo $9 / / \$$ is that evident the institution CL.dat CL.acc pays all 'Of course, the institution pays him everything.'

(C-Oral-Rom: EFAMDL26)

The question now is what are the factors that trigger doubling with nonpersonal pronouns? In order to answer this question, we conducted a Rbrul analysis of the subcorpus of non-personal pronouns with doubling vs. non-doubling as the dependent variable and various grammatical and semantic factors as independent variables. Table 4 gives an overview of the results.

$9 \quad$ Alternatively, examples with quantificational pronouns like todo in (15b) can be analyzed as examples for doubling of floating quantifiers (Tsakali, 2008). We will come back to this observation. 
Table 4: Rbrul analysis of the influence offactors on CD of non-personal pronouns in Peninsular and Rioplatense Spanish ${ }^{10}$

\begin{tabular}{|c|c|c|c|c|c|c|c|c|}
\hline & \multicolumn{8}{|c|}{ Non-personal pronouns } \\
\hline & \multicolumn{4}{|c|}{ Madrid } & \multicolumn{4}{|c|}{ Buenos Aires } \\
\hline & FW & $\begin{array}{r}\% \\
5.71 \%\end{array}$ & $\begin{array}{l}\mathrm{N} \\
50\end{array}$ & $\begin{array}{r}\text { TOTAL N } \\
875\end{array}$ & FW & $\begin{array}{r}\% \\
4.03 \%\end{array}$ & $\begin{array}{l}\mathrm{N} \\
27\end{array}$ & $\begin{array}{r}\text { TOTAL N } \\
670\end{array}$ \\
\hline \multicolumn{9}{|l|}{ Animacy/DOM } \\
\hline animate \& indirect object & 0.92 & $\mathbf{5 8 . 8 2 \%}$ & 10 & 17 & 0.98 & $90.91 \%$ & 10 & 11 \\
\hline animate $\&[+\mathrm{DOM}]$ & 0.48 & $25.00 \%$ & 6 & 24 & 0.39 & $28.57 \%$ & 4 & 14 \\
\hline inanimate \& [-DOM] & 0.08 & $3.55 \%$ & 29 & 817 & 0.03 & $1.90 \%$ & 12 & 631 \\
\hline inanimate $\&[+\mathrm{DOM}]$ & & $0.00 \%$ & 0 & 1 & & $0.00 \%$ & 0 & 1 \\
\hline animate \& [-DOM] & / & $8.33 \%$ & 1 & 12 & l & $7.69 \%$ & 1 & 13 \\
\hline range / $p$-value & 84 & & & & 95 & & & \\
\hline \multicolumn{9}{|l|}{ Person } \\
\hline first & 0.85 & $80.00 \%$ & 4 & 5 & & $100.00 \%$ & 4 & 4 \\
\hline third & 0.15 & $5.29 \%$ & 46 & 870 & & $3.45 \%$ & 23 & 666 \\
\hline range / $p$-value & 70 & & & & & & & \\
\hline \multicolumn{9}{|l|}{ Definiteness } \\
\hline definite & 0.80 & $6.79 \%$ & 45 & 663 & 0.70 & $4.43 \%$ & 23 & 519 \\
\hline indefinite & 0.20 & $2.36 \%$ & 5 & 212 & 0.30 & $2.65 \%$ & 4 & 151 \\
\hline range / $p$-value & 60 & & & & 40 & & & \\
\hline \multicolumn{9}{|l|}{ Negation } \\
\hline affirmative & 0.74 & $6.48 \%$ & 44 & 679 & [ ] & $4.96 \%$ & 25 & 504 \\
\hline negative & 0.26 & $3.06 \%$ & 6 & 196 & [ ] & $1.20 \%$ & 2 & 166 \\
\hline range / $p$-value & 48 & & & & & & & \\
\hline
\end{tabular}

10 Here and in the following tables, empty square brackets ('[ ]') indicate nonsignificant factor groups and slashes ('/) indicate exclusions of the respective factors from their factor groups in the statistical analysis due to too few tokens. The following factor groups have been selected as non-significant: Number, specificity (in Peninsular Spanish), null subject, clause type and infinitival clause. Categorical effects were obtained in Rioplatense Spanish (there were no specific 
When considering the non-personal object pronouns, the two dialects under study, Peninsular and Rioplatense Spanish, are remarkably parallel concerning the distribution of $\mathrm{CD}$ and its conditioning.

First of all, the overall distribution of $\mathrm{CD}$ with non-personal object pronouns is almost the same in the two dialects $(5.7 \%$ in Peninsular and $4.0 \%$ in Rioplatense Spanish). Second, the different independent variables tested reveal similar results.

In both dialects, doubling is categorical or nearly categorical with $1^{\text {st }}$ person object referents (16).

$$
\begin{array}{lllll}
\text { o sea } & \text { nos } & \text { las } & \text { quería } & \begin{array}{l}
\text { enseñar a todos } \\
\text { or be.SUBJ }
\end{array} \\
\text { CL.dat } & \text { CL.acc } & \text { wanted } & \text { show to all }
\end{array}
$$

'So he/she wanted to show them to all of us'.

(COLA Madrid: MAESB2-04c)

Additionally, due to a strong correlation between animacy and case (all indirect objects being animate and (almost) all direct animate objects being marked by DOM), we considered the two factors in combination. It turns out that $\mathrm{CD}$ is strongly favored with indirect and animate nominal objects in both varieties.

Another favoring effect for $\mathrm{CD}$ to occur with non-personal pronouns is the definiteness of the object pronouns in both Peninsular and Rioplatense Spanish. Finally, negation disfavors CD in Peninsular Spanish, showing the same, though non-significant, tendency in Rioplatense Spanish.

As for tonic personal pronouns, the statistical analysis shows that they are overwhelmingly doubled by a clitic in both subcorpora $(94.3 \%$ in Madrid and 95.8\% in Buenos Aires). There are only very few exceptions. In some cases (cf. 17), strong object pronouns can occur without being doubled if they represent arguments of reflexive verbs. In these cases, the occurrence of the reflexive pronoun $s e$ seems to prevent the occurrence of an additional clitic pronoun in the $1^{\text {st }}$ or $2^{\text {nd }}$ person. ${ }^{11} 12$

11 As pointed out by a reviewer, the absence of $\mathrm{CD}$ in this context cannot be attributed to the mere presence of the pronoun se because $\mathrm{CD}$ with 3rd person pronouns and non-pronominal DPs is possible: (i) Al hombre le parece que una mujer se le parece a ella.

(http://estonoesunarevista.com.ar/nro021/blablabla.html)

12 For the following three examples, we cannot provide an easy explanation.

One possibility is that the absence of the clitic pronoun is due to the very

colloquial character of the corpus.

i. ?sí bueno echando mano a él pero él no fue ahí de buen samaritano acompañándole tío

[COLA Madrid: MAESB2-01a]

ii. viste nosotros $[\ldots]$

saw us

'you saw us' [COLA Buenos Aires: BABAS4-1-3]

iii. me lo deja en la clase y dice a mí.

me it left in the classroom and said to me 

(17)a. hola gordo. a ver si se parece a ti hallo fat to see whether CL.refl ressembles DOM you 'Hi, guy. Let's see whether he/she ressembles you.'
(COLA Madrid: MABPE2-11a )
b. o la gente se engancha a ti / or the people CL.refl grab DOM you $\mathrm{y}$ te vas a cualquier sitio //\$ and yourself go to some place 'Or they grab you and you will go somewhere...'

(C-Oral-Rom: EFAMDL36)

As we have shown in the previous section, doubling is not as frequent with non-personal pronouns such as interrogative pronouns (e.g. a quién, qué 'whom, what'), indefinite pronouns (alguien, nadie 'someone, nobody'), quantificational pronouns (todo, todos, todas 'everything', 'all' (masc./fem. pl.)) and demonstrative pronouns (esto, ése, ésa 'this (neutr./masc./fem.)'). The factor analysis has shown that with these pronoun types, doubling is favored with 1st person referents, definiteness, indirect and animate objects. There is a clear and strong case asymmetry attested: indirect object pronouns are preferentially or (almost) obligatorily doubled, direct object pronouns are either optionally doubled ot not doubled at all.

The animate interrogative pronoun (a) quién ('who, (to) whom') occurs predominantly in the Buenos Aires corpus, whereas there is only one example in the Madrid corpus (18b). In the dative case, it is always doubled.

(18)a. a quién le hacés cucharital

to whom CL.dat make tender loving care

'With whom do you cuddle?' (COLA Buenos Aires: BABS2-02)
b. y que se lo mandó a no sé quién and that CL.dat CL.acc sent to not know whom
'And that (he/she) sent it to I don't know whom.'

(COLA Madrid: MAESB2-02)

There is only one apparent exception, where dative a quién occurs in combination with the verb mentir (19). This verb governs the dative case but constitutes a special case because it selects only one argument. It is therefore not clear whether the object of mentir represents a direct or an indirect object.

$$
\begin{aligned}
& \text { a quién mentís } \\
& \text { to whom lie } \\
& \text { 'to whom do you lie' }
\end{aligned}
$$

(COLA Buenos Aires: BABS2-02)

Quién occurs in the accusative only in the Buenos Aires corpus (20a-b). Doubling occurs optionally.

'(He/She) left it to me in the classroom and told it to me.' (COLA Buenos Aires: BABS2-03) 
(20) a. a quién tenemos ahoral

DOM who have now

'who do we have now.' (COLA Buenos Aires: BABS2-03)

b. a quién se la agarra/] ${ }^{13}$

DOM who refl. CL.acc takes

'to whom does he/she cling' (COLA Buenos Aires: BABAS4-1-14)

Example (20b) is interesting because such examples are considered to be ungrammatical by Jaeggli (1986) and Suñer (1988). In contrast, Di Tullio and Zdrojewski (2006) assume that a quién can be doubled provided that the whpronoun is somehow discourse-linked (d-linked):

\section{¿A quién lo premiaron esta vez? \\ DOM who CL.acc awarded this time}

'Who was awarded this time?' (Di Tullio \& Zdrojewski 2006:34)

In example (20b) the interrogative pronoun can be understood as d-linked in the sense that it refers to a presupposed set of individuals mentioned in the discourse, without referring to one specific entity of this set (two girls talking about other blond girls). Because (20b) is the only example in the corpus showing doubling with a quién, we cannot derive further conclusions about CD of interrogatives in Buenos Aires Spanish. ${ }^{14}$

The inanimate interrogative pronoun qué ('what') occurs in both corpora. It is restricted to accusative contexts and, in both subcorpora, it is not doubled by a clitic (22a-b).

(22)a. no sé qué dirá

not know what say

'I don't know what she/he will say.' (C-Oral-Rom Madrid: EFAMDL23)

b. contanos. qué estudiás/

tell-us what study

'Tell us what you study!'

(COLA Buenos Aires: BABAS4-1-5)

As in the case of interrogative pronouns, there are indefinite pronoun forms for animate (alguien 'someone') or inanimate (algo 'something') entities. In the dative case, animate alguien is frequently doubled by a clitic pronoun in both varieties $(23 a-b)$ :

13 Note that (20b) can not be understood as a possessive dative construction in which a quién would be interpreted as the possessor and the accusative clitic la as the possessee.

14 As pointed out by a reviewer, (20b) can also be taken as an example of the youthlanguage of Buenos Aires, which uses the combination of the verb agarrar and the reflexive pronoun se as some sort of metaphorical meaning ('to seduce'). According to this view, se in agarrarse is a diacritic marker distinguishing two lexemes: agarrar ('to grab') and agarrarse ('to seduce'). 
(23)a. porque yo se lo enseñe $^{15}$ a alguien

because I CL.dat CL.acc teach to someone

'Because I showed it to someone' (COLA Madrid: MAESB2-01b)

b. y después le da la corbata a alguien ${ }^{16}$

and afterwards CL.dat give the tie to someone

'And afterwards he/she gives the tie to someone.'

(COLA Buenos Aires: BABS2-03)

In the accusative case, alguien occurs without CD in the Buenos Aires (24a) and the Madrid corpus (24b).

(24)a. entonces necesitan a alguien que hable mucho.

so need DOM someone who speaks much

'So they need someone who speaks a lot.'

(COLA Buenos Aires: BABS2-08)

b. $\begin{array}{llll}\text { conoces a } & \text { alguien en Sevilla/ } \\ \text { snow DOMeone in Sevilla }\end{array}$

'Do you know someone in Sevilla?' (COLA Madrid: MAESB2-04b)

Inanimate algo ('something') only occurs as an accusative element and is not doubled (25a-b).

(25)a. acá quieren preguntar algo

here want to ask something

'Here they want to ask something.' (COLA Buenos Aires: BABS2-02)

b. tienes algo en la mano

have something in the hand

'You have something in your hand.' (COLA Madrid: MABPE2-05)

Quantificational pronouns like todo, todos, todas ('everything, everybody, all') occur both with and without being doubled by a clitic pronoun.

The plural forms todos/todas ('all') can refer to inanimate or animate referents. There is only one example of todas (animate) in the dative in each corpus. In both cases, the quantificational pronoun is doubled by a $1^{\text {st }}$ person pronoun nos (26a-b).

15 'enseñe' should be 'enseñé' in this example. We will not correct this because we follow the original corpus transcription.

16 There is one example in the Buenos Aires corpus, where indefinite a alguien cooccurs with an arbitrary null-object and is doubled by a clitic:

le puedo pedir a alguien\

CL.dat can ask DOM someone

'I can ask someone.' (BABS2-10) 
(26)a. nos quería decir algo a todas

CL.dat want to say something to all

'He/she wanted to say something to all of us.'

\section{b. $[<]<$ nos lo $>$ mandó a todas $/ / \$$}

(COLA Buenos Aires: BABS2-06)

CL.dat CL.acc sent to all

'He/she sent it to all of us.' (C-Oral-Rom Madrid: EFAMDL13)

In the accusative, todos/todas occurs in the Madrid corpus only with animate reference and is doubled (27a). Independent of animacy, accusative todos/todas occurs with and without CD in the Buenos Aires corpus (27b-e).

(27)a yolos veo a todos horribles (animate, accusative, MA, +CD)

I CL.acc see DOM all horrible

'I find all of them horrible.' (COLA Madrid: MAESB2-04c)

b. [los vi a todos ahí $]$ (animate, accusative, BA, +CD)

CL.acc saw DOM all there

'I saw everybody there.'

(COLA Buenos Aires: BABS2-03)

c. super capitán que dirige a todos. (animate, accusative, BA, -CD) super leader who directs DOM everybody

'a super leader who directs everybody.'

(COLA Buenos Aires: BABS2-04)

d. escondemos $\operatorname{todas}^{17}$ por acá (inanimate, accusative, BA, -CD) hide all Prep. there

'We hide them all over there.' (COLA Buenos Aires: BABS2-08)

e. hay que ganarlas todas ${ }^{18}$ (inanimate, accusative, $\mathrm{BA},+\mathrm{CD}$ )

one-has to win-CL.acc all

'One has to win them all.' $\quad$ (COLA Buenos Aires: BABS2-10)

The analysis of cases like (27a, b and e) as examples of CD is not uncontroversial. While Suñer (1988) and Estigarribia (2006) analyze these cases as instances of doubling, other authors favor an alternative analysis. Based on the observation that clitics co-occur with this kind of quantifiers also in languages which do not allow for CD (e.g. Pontic, Italian, French, Catalan, Serbo-Croatian), Tsakali (2008) argues that such examples represent cases of floating quantifiers.

Jean *(les) a invité tous.

(French)

Jean CL.acc has invited all

'Jean has invited them all.' (Tsakali 2008:195)

More concretely, this means that the clitic does not double a DP in argument position but represents in fact the argument of the quantifier (e.g. [tous [les amis]] 'all the friends') which has raised to a higher structural position in the clause by leaving the quantifier behind. This view is supported by the impossibility

17 In this example, todas refers to estas telas negras ('these black fabrics').

18 Todas refers to muchas batallas ('many battles'). 
of relating a quantifier to an element in A'-position due to cross-over effects (Tsakali 2008:201).

(29) a. *Pja ola ta agorase o Jianis?

which.acc all.acc CL.acc buy the John

(Greek)

'Which all did John buy?'

b. *Pjia ta agorase ola o Jianis?

c. *Pjia ta agorase o Jianis ola? (Tsakali 2008: 201)

In a similar vein, Ormazabal and Romero (2013) argue against the view that the co-occurrence of an accusative clitic and a universal quantifier as in (27a, $\mathrm{b}$ or e) represents a case of genuine $\mathrm{CD}$. One argument provided by the authors is the impossibility of examples like (30a) where the accusative clitic co-occurs with a quantifier embedding a pronoun. Based on the assumption that the accusative pronoun $l o$ is a clitic and the dative pronoun les is an agreement marker, Ormazabal and Romero (2013) show that in a Leísta dialect like Basque Spanish, only le is possible in the same configuration (30b). This implies that whenever lo occurs with a quantifier, it represents the argument of the quantifier that has raised out of the quantifier phrase.

(30)a. (*Los) he comprado todos ellos. (Ormazabal and Romero 2013: 307)

CL.acc have bought all them

'I have bought them all.'

b. Les han pillado a todos ellos

CL.dat(=acc) have caught DOM all them

'They have caught them all.' (Ormazabal and Romero 2013: 318)

However, the same analysis is not possible for the inanimate quantificational pronoun todo ('everything'). This quantificational pronoun occurs in the accusative case in both corpora and can be doubled or not by a clitic pronoun in both varieties (31a.-b.).

(31)a. por qué cree que lo sabe todo

because thinks that CL.acc knows everything

'Because he thinks he knows everything'.

(COLA Buenos Aires: BABAS4-1-16)

b. me tendrán que enseñar todo

CL.dat have to teach everything

'They will have to teach me everything.'

(C-Oral-Rom Madrid: EFAMDL13)

The fact that accusative todo can be doubled in both varieties casts doubt on the assumption that all cases including todos/todas represent cases of quantifier floating. Note that in languages that do not allow for CD (e.g. European Portuguese (EP)), the equivalent of the inanimate quantifier todo (=EP tudo) cannot be doubled (32a) although doubling of the equivalent of todos/todas (=EP todos/todas) is an option (32b). 

(32)a. Eu estou (*-o) a ouvir tudo.
I am (CL.acc) Prep. hear everything
'I'm just hearing everything.'
b. Punha(-os) todos no tabuleiro.
put (CL.acc) all on-the plate
'Put them all on the plate.'

Coming now to negative pronouns like nada/nadie ('nobody/nothing'), we find the following distribution in our corpus: in the dative, the animate negative pronoun nadie ('nobody') occurs only in the Madrid corpus. It occurs with and without CD (33a-b).

(33)a. yo no se lo he dado a nadie que lo oiga eh/ I not CL.dat CL.acc have given to nobody that it hear eh 'I have not given it to anybody who could hear it.'

(COLA Madrid: MAESB2-01b)

b. yo nunca voy a pegar un tiro a nadie

$\mathrm{I}$ never will $\mathrm{P}$ give a shot to nobody

'I will never shoot anybody.'

(COLA Madrid: MABPE2-05)

In the accusative, animate nadie is not doubled by a clitic (34).

[yo no obligo] [a nadie]

I not force DOM nobody

'I do not force anybody.'

(COLA Buenos Aires: BABS2-03)

The inanimate negative pronoun nada ('nothing') only occurs in the accusative and is not doubled by a clitic (35a-b).

(35)a. no porque nadie me había explicado nada no because nobody CL.dat has explained nothing

'No, because nobody had explained anything to me.'

b. nada nadie comió nada/ nothing nobody ate nothing

'Nobody ate anything.'

(COLA Madrid: MAESB2-04c)

Demonstrative pronouns do not occur in the dative in our corpus. The animate demonstrative ésto(s)/ésta(s) ('this one', masc./fem. pl.) occurs in the accusative only in the Madrid corpus where it can, but it does not need to be doubled by a clitic (36a-b). 
(36) a. habría que verla a ésta en un directo//\$ should that see-CL.acc DOM that in a live 'One should see her in a live session.' (C-Oral-Rom: EFAMDL24)

b. y luego ya he ido / a recoger a ésta and then already have gone / to collect DOM that one 'And then I already have gone to pick up that one.'

(C-Oral Rom Madrid: EFAMDL34)

Inanimate ésa ('that one') is also attested in the Madrid corpus and not doubled (37):

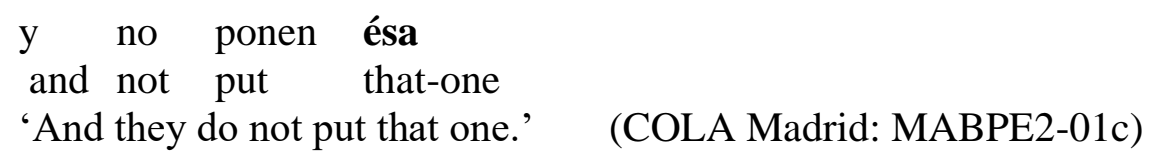

In the Buenos Aires Corpus, animate demonstratives are not attested in object position. The inanimate singular forms esto, ésalése ('this') occur with and without a clitic in the Buenos Aires Corpus (38a-d):

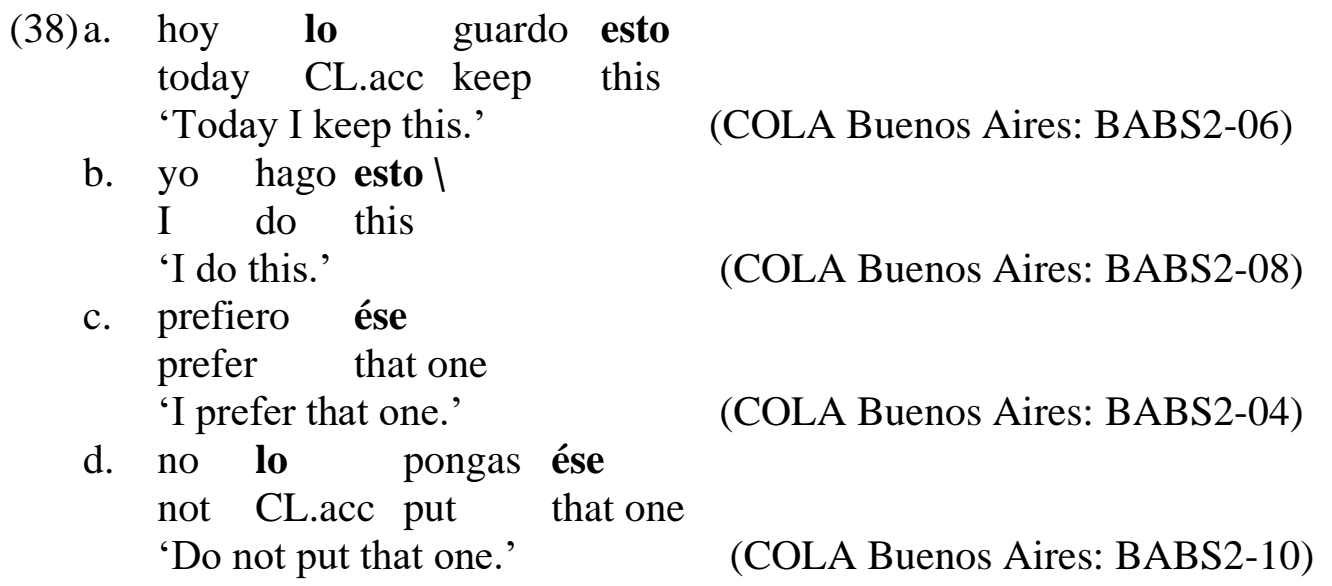

Although there is no prosodic break indicated in the transcription, we cannot fully exclude that the two isolated examples in (38a and d) have to be interpreted as cases of CLRD, as argued by Zdrojewski (2008), Saab and Zdrojewski $(2012,2013)$ and Di Tullio et al. (2019) with respect to the examples of clitic-doubled inanimate direct objects without DOM provided by Suñer (1988, cf. (8a-b)). Although the referent is not mentioned in the preceding dialog, the use of a demonstrative indicates that the object refers to a salient referent.

As the comparison shows, the two dialects behave very similarly concerning the factors favoring $\mathrm{CD}$ with non-personal pronouns. The difference between them is gradual: doubling with indirect objects (which are in general animate) is strongly favored in Madrid (10 out of 17) and almost categorical in Buenos Aires (10 out of 11). In the accusative, doubling is very restricted. In general, accusative non-personal pronouns are not doubled with potential exceptions of quantitative and demonstrative pronouns (but see the discussion above). The following table (with MA referring to Madrid and BA to Buenos Aires) summarizes our findings. 
Table 5: Generalizations concerning CD of non-personal pronouns in the two dialects

\begin{tabular}{|c|c|c|c|}
\hline pronoun & $\begin{array}{c}\text { dative } \\
\text { (animate) }\end{array}$ & accusative animate & $\begin{array}{l}\text { accusative } \\
\text { inanimate }\end{array}$ \\
\hline $\begin{array}{c}\text { interrogative } \\
\text { pronouns }\end{array}$ & $\begin{array}{l}\text { (a quién'to } \\
\text { whom') }\end{array}$ & $\begin{array}{c}\text { (a quién '(DOM) } \\
\text { whom')) }\end{array}$ & (qué 'what') \\
\hline MA & $+\mathrm{CD}$ & n.a. & $-\mathrm{CD}$ \\
\hline $\mathbf{B A}$ & $+\mathrm{CD}$ & $(+) /-C D$ & $-\mathrm{CD}$ \\
\hline $\begin{array}{l}\text { indefinite } \\
\text { pronouns }\end{array}$ & $\begin{array}{l}\text { (a alguien 'to } \\
\text { someone') }\end{array}$ & $\begin{array}{c}\text { (a alguien '(DOM) } \\
\text { someone') }\end{array}$ & $\begin{array}{c}\text { (algo } \\
\text { 'something') }\end{array}$ \\
\hline MA & $+\mathrm{CD}$ & $-\mathrm{CD}$ & $-\mathrm{CD}$ \\
\hline BA & $+\mathrm{CD}$ & $-\mathrm{CD}$ & $-\mathrm{CD}$ \\
\hline $\begin{array}{c}\text { quantificational } \\
\text { pronouns }\end{array}$ & $\begin{array}{c}\text { (a todos/todas } \\
\text { 'to all, } \\
\text { everybody') }\end{array}$ & $\begin{array}{c}\text { (a todos, a todas } \\
\text { '(DOM) all, } \\
\text { everybody') }\end{array}$ & $\begin{array}{c}\text { (todo } \\
\text { 'everything') }\end{array}$ \\
\hline MA & $+\mathrm{CD}$ & $+\mathrm{CD}$ & $+/-\mathrm{CD}$ \\
\hline BA & $+\mathrm{CD}$ & $+/-\mathrm{CD}$ & $+/-\mathrm{CD}$ \\
\hline $\begin{array}{c}\text { negative } \\
\text { pronouns }\end{array}$ & $\begin{array}{l}\text { (a nadie 'to } \\
\text { nobody') }\end{array}$ & $\begin{array}{c}\text { (a nadie '(DOM) } \\
\text { nobody') }\end{array}$ & $\begin{array}{c}\text { (nada } \\
\text { 'nothing') }\end{array}$ \\
\hline Madrid corpus & $+/-\mathrm{CD}$ & $-\mathrm{CD}$ & $-\mathrm{CD}$ \\
\hline $\begin{array}{c}\text { Buenos Aires } \\
\text { corpus }\end{array}$ & n.a. & $-\mathrm{CD}$ & $-\mathrm{CD}$ \\
\hline $\begin{array}{c}\text { demonstrative } \\
\text { pronouns }\end{array}$ & n.a. & $\begin{array}{l}\text { (a ésta }(s), \text { a ésto(s) } \\
\text { '(DOM) this, those, } \\
\text { this one }(\mathrm{s}) \text { ') }\end{array}$ & $\begin{array}{c}\text { (esto, ésa, ése } \\
\text { 'this') }\end{array}$ \\
\hline Madrid corpus & n.a. & $+/-\mathrm{CD}$ & $-\mathrm{CD}$ \\
\hline $\begin{array}{l}\text { Buenos Aires } \\
\text { corpus }\end{array}$ & n.a. & n.a. & $+/-\mathrm{CD}$ \\
\hline
\end{tabular}




\subsection{Doubling of nominal objects}

In the following section we have a closer look at $\mathrm{CD}$ of dative and accusative nominal objects in the two varieties of Spanish. We first compare the proportion of accusative and dative nominal objects within both corpora and second the proportion of $\mathrm{CD}$ of direct nominal objects across the two varieties. In a third step, we have a closer look at the different factors determining $\mathrm{CD}$ of nominal objects.

Table 6 and 7 present the overall proportions of $\mathrm{CD}$ of dative and accusative nominal objects.

Table 6: Proportion of doubling of accusative and dative noun phrases in COLA Madrid + C-Oral ROM

\begin{tabular}{|c|c|c|c|c|}
\hline \multicolumn{5}{|c|}{ COLA Madrid + C-Oral-Rom } \\
\hline \multirow{2}{*}{ Accusative } & doubling & 17 & N & N (\%) \\
\cline { 2 - 5 } noun phrase & non-doubling & 3106 & 99.5 & \multirow{2}{*}{$3123(100)$} \\
\hline \multirow{2}{*}{$\begin{array}{c}\text { Dative noun } \\
\text { phrase }\end{array}$} & doubling & 90 & 81.8 & \multirow{2}{*}{$110(100)$} \\
\cline { 2 - 5 } & non-doubling & 20 & 18.2 & \\
\hline$\Sigma$ & & & & 3233 \\
\hline
\end{tabular}

In Peninsular Spanish, CD is a characteristic property of indirect objects. As expected, direct objects represent an extremely unfavorable context for CD in this variety. A Chi-Square test shows that the difference between the proportions of doubling of accusative and dative noun phrases is significant in Peninsular Spanish $\left(\chi^{2}=2193.3054 ; p<0.001\right.$ (highly significant)). 
Table 7: Proportion of doubling of accusative and dative noun phrases in COLA Buenos Aires

\begin{tabular}{|c|c|c|c|c|}
\hline \multicolumn{5}{|c|}{ COLA Buenos Aires } \\
\hline \multirow{2}{*}{ Accusative } & doubling & 48 & N & N (\%) \\
\cline { 2 - 5 } noun phrase & non-doubling & 1305 & 96.5 & \multirow{2}{*}{$1353(100)$} \\
\hline Dative noun & doubling & 75 & 91.5 & \multirow{2}{*}{$82(100)$} \\
\cline { 2 - 5 } phrase & non-doubling & 7 & 8.5 & $\mathbf{1 4 3 5}$ \\
\hline$\Sigma$ & & & & \\
\hline
\end{tabular}

As for Rioplatense, the difference between accusative and dative nominal objects is significant as well $\left(\chi^{2}=762.5317, p<0.001\right.$ (highly significant)). This means that the observation made for Peninsular Spanish that indirect nominal objects are typically doubled can also be confirmed for Rioplatense Spanish. The rate of doubling with accusative nominal objects is significantly higher in the Buenos Aires corpus than in the Madrid corpus $\left(\chi^{2}=59.4995, p<0.001\right.$ (highly significant)). Examples (39a-b) illustrate accusative $\mathrm{CD}$ of direct objects in the Buenos Aires corpus, example (39c) is from the Madrid corpus.

(39) a. diciendo que no se la bancan a nanu<nombre>/ digo yo saying that not CL.imp CL.acc stand DOM Nanu/ say I 'saying that they cannot stand Nanu, I am saying' (COLA BA: BABS41-1)

b. yo no la conozco a la mina I not CL.acc know DOM the girl 'I do not know the girl.'

c. se lo doy el papel o quél CL.dat CL.acc give the paper or what 'I'll give him/her the paper, or what?'

(MABPE2-09)

Although doubling of accusative nominal objects is quite rare in both corpora, we conclude on the basis of our results that there is indeed a difference between the two varieties of Spanish: doubling of accusative noun phrases is virtually absent in Peninsular Spanish but systematically attested in Rioplatense Spanish. Hence, our corpus study confirms what has been concluded on the basis of isolated examples, introspective judgments and other corpus data for Buenos Aires Spanish (Barrenechea \& Orecchia, 1970/71) in earlier studies. Nevertheless, $\mathrm{CD}$ of direct nominal objects cannot be dismissed as ungrammatical in Peninsular 
Spanish as it is attested in our corpus and occurs in 17 cases. Before we discuss some examples in more detail, we present our results concerning our third research question, namely, the role of DOM and the semantic factors in CD of direct and indirect object noun phrases. Table 8 presents the results of a logistic regression analysis performed with Rbrul, testing the influence of a number of morphological, semantic and pragmatic factors on the choice of $\mathrm{CD}$ with indirect objects in Peninsular and Rioplatense Spanish.

Table 8: Rbrul analysis of the influence of factors on $C D$ of indirect nominal objects in Peninsular and Rioplatense Spanish 19

\begin{tabular}{|c|c|c|c|c|c|c|c|c|}
\hline & \multicolumn{8}{|c|}{ Indirect object DPs } \\
\hline & \multicolumn{4}{|c|}{ Madrid } & \multicolumn{4}{|c|}{ Buenos Aires } \\
\hline & FW & $\%$ & $\mathrm{~N}$ & TOTAL N & FW & $\%$ & $\mathrm{~N}$ & TOTAL N \\
\hline & & $81.82 \%$ & 90 & 110 & & $91.46 \%$ & 75 & 82 \\
\hline \multicolumn{9}{|l|}{ Animacy } \\
\hline animate $\&$ indirect object & & & & & & & & \\
\hline animate & l & $84.69 \%$ & 83 & 98 & [ ] & $92.41 \%$ & 73 & 79 \\
\hline inanimate & I & $58.33 \%$ & 7 & 12 & [ ] & $66.70 \%$ & 2 & 3 \\
\hline \multicolumn{9}{|l|}{ range / $p$-value } \\
\hline \multicolumn{9}{|l|}{ Theta Role } \\
\hline Benefactive & 0.78 & $\mathbf{8 8 . 8 9 \%}$ & 8 & 9 & [ ] & $85.71 \%$ & 6 & 7 \\
\hline Goal & 0.69 & $85.87 \%$ & 79 & 92 & [ ] & $91.55 \%$ & 65 & 71 \\
\hline Source & 0.12 & $33.33 \%$ & 3 & 9 & & $100.00 \%$ & 4 & 4 \\
\hline range / $p$-value & 66 & & & & & & & \\
\hline \multicolumn{9}{|l|}{ Specificity } \\
\hline specific & 0.77 & $92.05 \%$ & 81 & 88 & [ ] & $92.96 \%$ & 66 & 71 \\
\hline non-specific & 0.23 & $40.91 \%$ & 9 & 22 & [ ] & $81.82 \%$ & 9 & 11 \\
\hline range / $p$-value & 54 & & & & & & & \\
\hline \multicolumn{9}{|l|}{ Negation } \\
\hline affirmative & I & $82.24 \%$ & 88 & 107 & 0.70 & $94.44 \%$ & 68 & 72 \\
\hline negative & l & $66.67 \%$ & 2 & 3 & 0.30 & $66.67 \%$ & 6 & 9 \\
\hline range / $p$-value & & & & & 40 & & & \\
\hline \multicolumn{9}{|l|}{ Number } \\
\hline plural & [ ] & $56.25 \%$ & 9 & 16 & & $100.00 \%$ & 13 & 13 \\
\hline singular & [ ] & $86.17 \%$ & 81 & 94 & & $89.86 \%$ & 62 & 69 \\
\hline range / $p$-value & & & & & & & & \\
\hline
\end{tabular}

19 In the Peninsular data, due to interactions, only those factor groups have been subjected to a step up/step down analysis which have been selected as significant at the $10 \%$ level in the preceding one-level analysis. These included: definiteness, number, sentential objects, specificity and theta role (amongst which only the 
As already mentioned before, indirect object DPs are preferentially doubled by a clitic pronoun in both Argentinian and Peninsular Spanish. Only a minority of less than 20\% remain undoubled in Peninsular Spanish and even less than $10 \%$ in Argentinian Spanish. In Argentinian Spanish, plural number is categorically doubled (cf. 40).

$$
\begin{array}{llllll}
\text { yo ya les canté a } & \text { los } & \text { pobres } \\
\text { I already } & \text { CL.acc } & \text { sang } & \text { to } & \text { the } & \text { poor } \\
\text { 'I already sang to the poor people.' } & & & \text { (COLA }
\end{array}
$$

(COLA BA: BABS2-02)

In addition, affirmative polarity seems to have a favoring effect. However, the effects of plural and affirmation are probably due to very low numbers. Overall, the numbers reveal that doubling with indirect objects has become almost categorical in Rioplatense Spanish. In Peninsular Spanish, two factors turn out to represent favorable contexts for CD: indirect object nouns with the thematic role of benefactive or goal and specific reference.

Table 9 provides the results of a logistic regression analysis, testing the influence of different factors on $\mathrm{CD}$ with direct objects in Peninsular and Rioplatense Spanish.

latter two attained statistical significance in the step up/step down analysis). The remaining factor groups were excluded from the analysis, as indicated by the slashes ('/'). In the Rioplatense data, the following factor groups were selected as non-significant: animacy, definiteness, sentential objects, specificity, null subjects, clause type, infinitival complements, proper names and theta role. 
Table 9: Rbrul analysis of the influence of factors on CD of direct nominal objects in Peninsular and Rioplatense Spanish

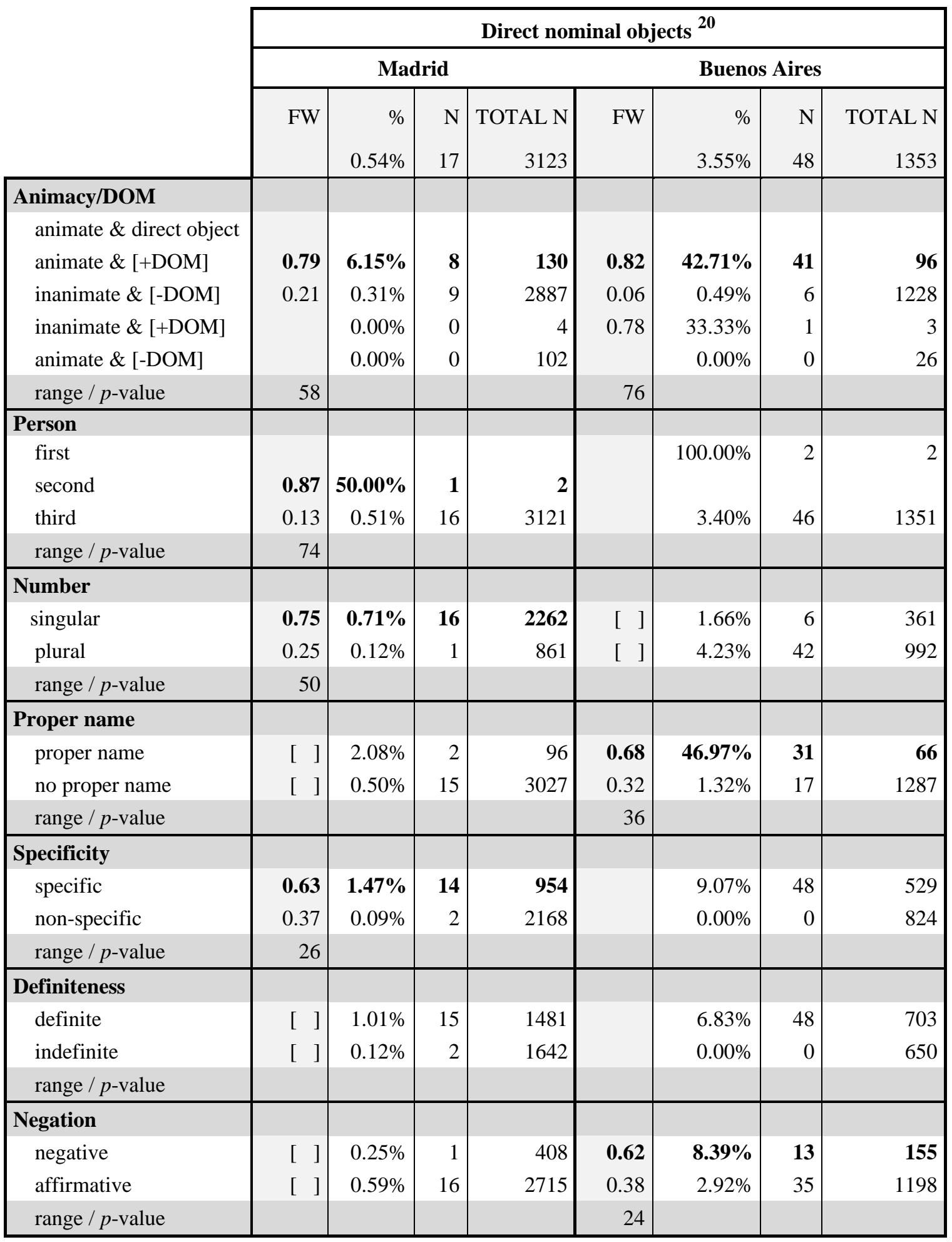


In Peninsular Spanish, direct nominal objects are virtually never doubled. Out of 3123 tokens, only 17 appear with a doubled object clitic (0.5\%). In this respect, direct objects are in considerable contrast with indirect objects where doubling accounts for more than $80 \%$ of the cases. There is a favoring effect of singular number (and a disfavoring effect of plural) as well as a favoring effect of second person, but we believe that due to the overall extremely low number of tokens, these effects should not be overestimated. According to our analysis, favoring factors of $\mathrm{CD}$ of direct objects in the Madrid corpus are specificity and animacy in combination with DOM. In the COLA Buenos Aires corpus, CD of direct object nouns occurs in $3.5 \%$ of all cases. The examples categorically include a specific and definite object. Animacy in combination with DOM also significantly favors the use of $\mathrm{CD}$ which is also reflected by the favoring effect of proper names. In the reminder of this section, we discuss some examples in more detail. We start with dative nominal objects and continue with direct nominal objects.

As mentioned in the previous section, doubling of indirect nominal objects in Peninsular Spanish is in general very frequent and it is favored by the thematic role of benefactive or goal (41a) and specific reference (41b).

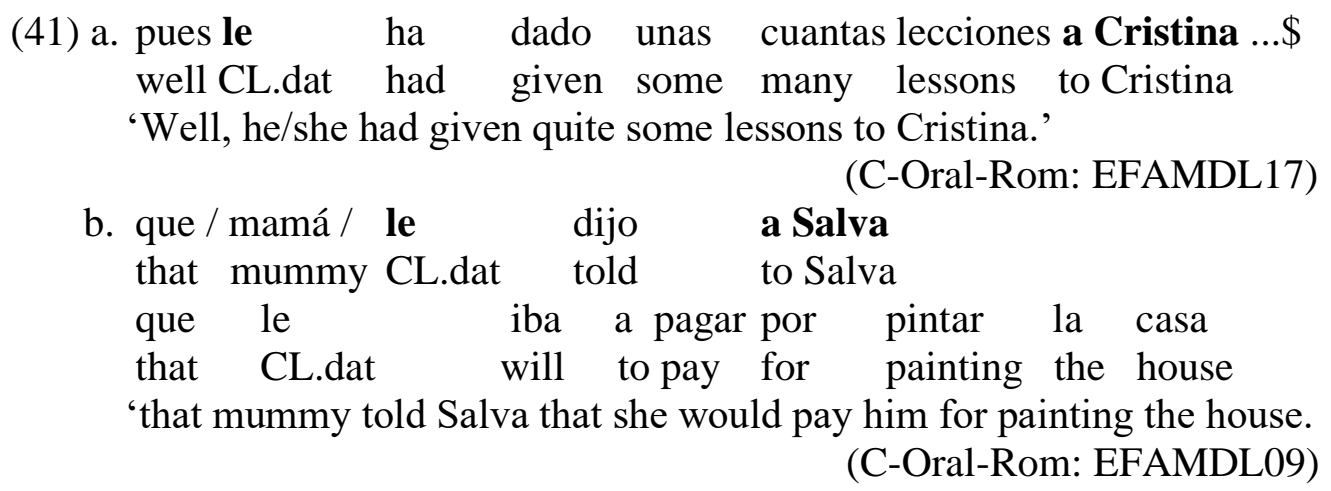

Non-specific indirect objects do not represent a favoring context in Madrid Spanish; they occur more often without CD than with CD. In example (42a), the non-specific dative object is doubled, in (42b) it is not.

20 In the Peninsular data, the factor groups negation, quantifier, definiteness and proper name were selected as non-significant. In the Rioplatense data, the factor groups number, sentential object and infinitival complement obtained nonsignificant results. Clause type and null subject were non-significant in both corpora. Besides the categorical effect of specificity and definiteness on CD in the Rioplatense data, further effects of categoricity could be observed: In the Peninsular data, CD neither occurred with sentential objects nor with infinitival complements. In the Rioplatense data, CD was absent in combination with quantifiers and did not show variation with regard to person. 


a. pero no es lo mismo /
but not is the same
explicarles
to explain-CL.dat the things to a friend
'But it is not the same to explain the things to a friend.'
b. no echás pirópos a a una tercera
not throw compliments to a third
'do not throw compliments to a third one'

(COLA Madrid: MABPE2-05)

In contrast to the Madrid corpus, where specificity is a favoring factor (and non-specificity a disfavoring factor) for $\mathrm{CD}$, in the corpus of Buenos Aires, nonspecific indirect object nouns are doubled almost as often as specific ones. We conclude that $\mathrm{CD}$ of indirect objects has extended to non-specific nominal objects in Rioplatense Spanish and therefore, specificity no longer plays a role. In fact, CD of indirect nominal objects in Buenos Aires Spanish is independent of the factors included in our analysis and can be described as virtually categorical (cf. Pujalte and Saab 2018). If we assume that ongoing processes of grammaticalization are characterized by the fact that particular referential features become less relevant (or distinctive) (=desemanticization) and that, consequently, the construction extends to new contexts of occurrence, we may conclude that Rioplatense Spanish is ahead of Peninsular Spanish concerning the distribution of CD with indirect nominal objects.

In Peninsular Spanish, specificity has the same statistically significant effect favoring CD of direct object nouns as in the case of indirect object nouns: Like indirect objects, direct objects are more often doubled if the object noun phrase is specific. Animacy in combination with DOM is also a favoring factor for CD of direct nominal objects in the Madrid corpus (43a). However, animacy and DOM are not mandatory for doubling to occur (43b).
(43) a. que siempre lo veo al tío jodido
that always CL.acc see DOM-the guy broken
'that I always see this broken guy' (COLA Madrid: MAESB2-03)
b. te lo regalan luego el minidisc/ ${ }^{21}$
CL.dat CL.acc give then the minidisc
'Then they will give you the minidisc.' (COLA Madrid: MAESB2-01b)

In the Buenos Aires corpus, only specific and definite direct nominal objects are doubled. The restriction to definite direct objects may be related to the limitations of the corpus. Pujalte et al. (2017) provide some attested examples, which were tested with native speakers of Rioplatense Spanish. One example is given in (44).

$21 \quad$ This example was not counted as a case of clitic right dislocation because the adverb is short and an intonational break ('/') was indicated in the transcription after the object (see section 3.2). 


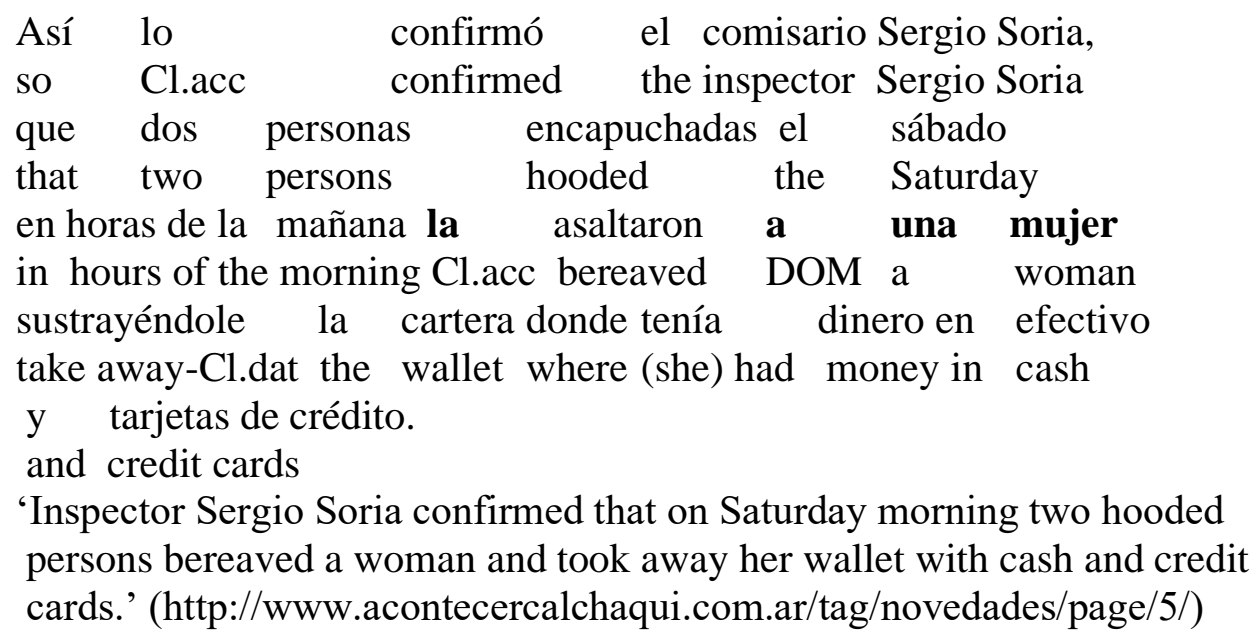

As in Peninsular Spanish, animacy in combination with DOM also significantly favors the use of CD (ex. 45a.) in Rioplatense Spanish. CD never occurred with animate nouns lacking DOM. Inanimate nouns occur in only three cases with DOM, one of which has CD (45b). In six cases, inanimate nouns without DOM are attested with CD (45c).

\section{(45) a. la viste a Sandra \\ CL.acc saw DOM Sandra} 'you saw Sandra'

b. hoy lo vienen a buscar al aparatito este today CL.acc come to pick up DOM-the machine this 'Today they will come to pick up this machine.'

(CORAL Buenos Aires: BABS2-04)
c. estirálas
bien las piernas estirálas ${ }^{22}$
strech out.CL.acc well the legs strech out.them.CL
'Stretch out your legs, stretch them out well!'

(CORAL Buenos Aires: BABS2-02)

As discussed in section 4.1, similar examples provided by Suñer (1988) have been analyzed as cases of CLRD by Zdrojewski (2008), Saab and Zdrojewski (2012, 2013) and Di Tullio et al. (2019). Because we deal with spontaneous corpus data and cannot apply the diagnostics used in these works, we cannot completely exclude that such examples might be cases of CLRD. Given the absence of indications for a dislocation analysis, we decided to include these examples as instances of CD. Prosodically, the object is not separated from the rest of the sentence by a prosodic break. The discourse context does not provide evidence for a topic interpretation of the object either although the referents represent salient information.

Summarizing the comparison between Rioplatense and Peninsular Spanish, the results show that doubling of indirect nominal objects is almost

22 This example was considered to be a case of $\mathrm{CD}$, although the adverb bien intervenes between the finite verb and the object DP. According to DiTullio \& Zdrojewski (2006:25) only elements that can bear a primary accent (such as subjects) can be counted as indicators of clitic right disclocation. Quantificational or aspectual adverbs do not seem to have this property. 
categorical in Rioplatense and strongly preferred in Peninsular Spanish, where the thematic role of benefactive or goal and specificity are favoring factors. CD of direct nominal objects is significantly more frequent in Rioplatense and subject to similar contextual and semantic conditions in both dialects (e.g. animacy in combination with DOM, specificity (definiteness)). These findings are summarized in the following table.

Table 10: Generalizations concerning CD of nominal objects in the two dialects

\begin{tabular}{|c|c|c|}
\hline & Madrid & Buenos Aires \\
\hline $\begin{array}{l}\text { indirect nominal } \\
\text { objects }\end{array}$ & $\begin{array}{l}\text { favorable effects of } \\
\text { specific reference (+the } \\
\text { thematic role of } \\
\text { benefactive or goal) }\end{array}$ & $\begin{array}{l}\text { almost categorical } \\
\text { effects of plural number } \\
\text { and affirmative polarity } \\
\text { (but only small numbers } \\
\text { of tokens) }\end{array}$ \\
\hline direct nominal objects & $\begin{array}{l}\text { very low number of } \\
\text { tokens } \\
\text { favoring effect of } \\
\text { singular number (and a } \\
\text { disfavoring effect of } \\
\text { plural) and second } \\
\text { person/favoring effects of } \\
\text { specificity and } \\
\text { animacy+DOM }\end{array}$ & $\begin{array}{l}\text { categorical effects of } \\
\text { definiteness and } \\
\text { specificity } \\
\text { favoring effects of } \\
\text { animacy+DOM }\end{array}$ \\
\hline
\end{tabular}

\section{Summary and conclusion}

Our study has shown that CD is indeed a variable phenomenon both within and across the two varieties of Rioplatense and Peninsular Spanish. Despite some remarkable differences between the Buenos Aires and the Madrid corpus, CD is determined by the same influencing factors in both corpora.

The variability of $\mathrm{CD}$ in our corpora leads us to the conclusion that there are, on the one hand, necessary conditions and, on the other hand, favoring factors for $\mathrm{CD}$ in the contexts where it is possible. Based on our research questions, we discuss these conditions and factors in the remainder of this section. 
Coming back to our first research question concerning the role of the feature [+/-pronominal], its interaction with other features and the determining factors of doubling with non-personal pronouns, we come to the following conclusions:

The first observation is that only a subclass of pronouns - stressed personal pronouns - is almost categorically doubled in both varieties. Because other (nonpersonal) pronouns do occur without doubling, it cannot be the case that a categorial feature [+/- pronominal] causes or enables the occurrence of $\mathrm{CD}$. That the syntactic category of the object does not have an influence is expected if we assume that full/strong pronouns and noun phrases in argument position are (in general) Determiner phrases (DPs, Longobardi 1994), hence, belong to the same syntactic category.

The second conclusion is that pronouns must meet two conditions for CD to be possible: dative case marking and/or definiteness. As we have seen, all dative and some definite accusative pronouns (e.g. quantificational pronouns or demonstratives) $)^{23}$ occur with $\mathrm{CD}$ in our corpus. Indefinite accusative pronouns are not doubled.

Concerning our second research question - the role of case - our study has shown that dative case also allows CD of nominal objects. Although dative objects are frequently definite, specific and animate, dative case enables CD independently of these features as inanimate and animate as well as specific and non-specific dative objects occur with $\mathrm{CD}$ in our corpus.

That doubling of indefinite and non-specific datives is equally possible as doubling of definite and specific datives has been illustrated with respect to the indefinite pronoun alguien and the non-specific negative pronoun nadie which occur both with CD in our corpus. We conclude that doubling of dative arguments is always possible in Spanish. Without going into the details of the syntactic analysis, we assume that double object constructions involve an applicative head (cf. Pineda 2013) which can, but needs not, be realized by the clitic le. How often a speaker makes use of this option depends on the referential features of the dative object and can also be subject to individual preferences. We conclude that dative case marking is a sufficient condition for $\mathrm{CD}$ to be possible and that in its presence, definiteness, specificity and animacy are favoring factors for $C D$ to occur.

What has been said so far about indirect or dative objects is in principle true for both varieties. There are however some interesting differences between Buenos Aires Spanish and Spanish from Madrid: first, both with respect to non-personal pronouns in the dative and with respect to indirect nominal objects, CD is more frequent in Rioplatense Spanish than in Peninsular Spanish. In fact, CD with dative nouns and pronouns is almost categorical in Buenos Aires. In Madrid, CD is also preferred with datives, but less frequent and - with indirect nominal phrases - it shows a favoring effect of specificity. Interestingly, non-specificity was a predicting factor for the absence of CD of dative DPs in Madrid, but not in Rioplatense, where semantic factors were irrelevant for doubling of dative nominal objects. This dialectal difference can be interpreted as evidence in favor of an advancement of the Buenos Aires variety on the proposed referential hierarchies

${ }^{23}$ But see the discussion in 4.1 concerning floating quantifiers / potential cases of CLRD. 
(cf. Leonetti, 2007a; Sánchez and Zdrojewski, 2013; Pujalte and Saab, 2018), if we assume that in each step, semantic features are initially relevant and subsequently lose their significance when doubling becomes generalized in the respective context.

Our third research question concerns the relation between $\mathrm{CD}$ of direct objects and DOM in the corpora and the role of semantic factors (definiteness, specificity, animacy). Overall, $\mathrm{CD}$ is less frequent with direct objects than with indirect objects in both varieties. In the Madrid corpus, $\mathrm{CD}$ of direct nominal objects is very rarely attested. For pronouns in our corpora, DOM cannot be easily differentiated from animacy because there are no inanimate non-personal pronouns marked by DOM. Animate non-personal pronouns can occur with and without DOM and with and without doubling in both varieties. CD is more frequent if DOM is present, but the presence of DOM alone does not necessarily trigger CD of animate direct objects if the object is indefinite and non-specific as alguien. In some examples, CD occurs in the absence of DOM (but see the discussion of the relevant examples in 4.1).

The same is true for direct nominal objects: in both corpora, animate nominal objects in the accusative can, but need not, be marked by DOM. In the Buenos Aires corpus, DOM-marked animate direct nominal objects are doubled at a rate of $42.4 \%$, but only at a rate of $6.1 \%$ in the Madrid corpus. Just like in the case of direct non-personal pronouns, there are also some cases where the accusative nominal object occurs with CD in the absence of DOM.

Because $\mathrm{CD}$ of direct nominal objects is extremely infrequent and concerns only isolated examples, not much can be said about the role of semantic factors in Peninsular Spanish. In Rioplatense Spanish, semantic factors are strongly involved (definiteness, specificity, animacy) in $\mathrm{CD}$ of direct nominal objects. In fact, definiteness (and specificity) are categorical features of clitic doubled direct nominal objects in our corpus.

Our fourth research question concerning the similarities and differences between the two varieties of Spanish and the role of the suggested implicational hierarchy has partially already been addressed. In general, we can confirm the following implications which hold for both varieties:

\section{(46) Implicational relations}

- $\mathrm{CD}$ of non-personal pronouns/nouns implies doubling of personal pronouns

- $\mathrm{CD}$ of accusative objects implies doubling of datives

- CD of indefinite objects implies CD of definite objects

- CD of non-specific objects implies doubling of specific objects

These implicational relations can be ordered in the following way (47), which (at least partially) confirm Leonetti's (2007a) and Fischer and Rinke's (2013) proposals presented in section 1: 
(47) Implicational scale of $C D$ :

strong personal pronouns < datives $<$ definite descriptions $<$ specific indefinites $<$ non-specific indefinites

In contrast to the Madrid corpus, the difference between pronominal and non-pronominal objects has lost statistical significance in Rioplatense Spanish and $\mathrm{CD}$ of dative nominal objects has generalized. In our corpus, doubling of direct object DPs categorically involves specific and definite objects in Rioplatense. This points into the direction of an advancement of the Buenos Aires variety along the proposed referential hierarchy.

\section{References}

Aissen, Judith. 2003. Differential object marking: Iconicity vs. economy. Natural Language \& Linguistic Theory 21, 435-483.

https://doi.org/10.1023/a:1024109008573

Anagnostopoulou, Elena. 2003. The syntax of ditransitives: Evidence from clitics. Berlin: de Gruyter.

Astruc, Lluisa. 2005. The intonation of sentence-external elements in Catalan and English. Ph.D. Thesis, University of Cambridge.

Gabriel, Christoph \& Rinke, Esther. 2010. Information packaging and the rise of clitic doubling in the history of Spanish. In G. Ferraresi \& R. Lühr (eds.), Diachronic Studies on Information Structure. Language Acquisition and Change (Language, Context and Cognition 10), 63-86. Berlin: de Gruyter. https://doi.org/10.1515/9783110227475.63

Fischer, Susann \& Rinke, Esther. 2013. Explaining the variability of clitic doubling across Romance: a diachronic account. Linguistische Berichte 236, 255-272.

Baker, Mark C. 2008. The macroparameter in a microparametric world. In T. Biberauer (ed.), The limits of syntactic variation, 351-374. Amsterdam/Philadelphia: John Benjamins. https://doi.org/10.1075/la.132.16bak

Barrenechea, Ana María \& Orecchia, Teresa. 1970/1971. La duplicación de objetos directos e indirectos en el español hablado en Buenos Aires. RomPhil 24, 58-83.

Barrenechea, Ana María \& Orecchia, Teresa. 1977. La duplicación de objetos directos e indirectos en el español hablado en Buenos Aires. In J.M. Lope Blanch (ed.), Estudios sobre el español hablado en las principales ciudades de América, 351-381. México: Universidad Autónoma de México. https://doi.org/10.2307/472804

Barrenechea, Ana María (ed.) 1987. El habla culta de la ciudad de Buenos Aires. Materiales para su estudio (tomo 2). Buenos Aires: Inst.de Fil. y Lit. https://doi.org/10.31819/9783964569578-010 
Becerra Bascuñán, Silvia. 2006. Estudio diacrónico y sincrónico del objeto indirecto en el español peninsular y de América. København: Museum Tusculanum. https://doi.org/10.26530/oapen_342355

Belloro, Valeria A. 2007. Spanish clitic doubling: A study of the syntaxpragmatics interface. Ph.D. Thesis, State University of New York at Buffalo.

Bleam, Tonia. 2000. Leista Spanish and the syntax of clitic doubling. Ph.D. Thesis, University of Delaware.

Bossong, Georg. 1985. Empirische Universalienforschung. Differentielle Objektmarkierung in den neuiranischen Sprachen. Tübingen: Narr.

Chafe, Wallace. 1987. "Cognitive constraints on information flow". In R. Tomlin (ed.), Coherence and grounding in discourse, 21-52. Amsterdam: John Benjamins Publishing Company.

Chafe, Wallace. 1994. Discourse, consciousness and time. Chicago: The University of Chicago Press.

Colantoni, Laura. 2002. Clitic doubling, clitic climbing and null objects in the Spanish of Corrientes (Argentina). In J. Gutiérrez-Rexach (ed.), From Words to Discourse. Trends in Semantics and Pragmatics, 321-336. Oxford: Elservier.

Company Company, Concepción. 2003. La gramaticalización en la historia del español. In C. Company (ed.), Gramaticalización y cambio sintáctico en la historia del español, 1-62. Mexico: Universidad Nacional Autónoma de México. https://doi.org/10.3989/rfe.2004.v84.i1.97

Cresti, Emanuela \& Moneglia, Massimo. 2005. C-ORAL-ROM. Integrated reference corpora for spoken Romance languages. Amsterdam: John Benjamins Publishing Company. https://doi.org/10.1007/s10590-007-9025-y

Déchaine, Rose-Marie \& Wiltschko, Martina. 2002. "Decomposing pronouns". Linguistic Inquiry 33(3), 409-442. https://doi.org/10.1162/002438902760168554

Di Tullio, Ángela \& Zdrojewski, Pablo. 2006. Nota sobre el doblado de clíticos en el español rioplatense: asimetría entre objetos humanos e no humanos. Filología XXXVIII: 13-44.

Di Tullio, Ángela, Saab, Andrés \& Zdrojewski, Pablo. 2019. Clitic doubling in a doubling world. The case of Argentinean Spanish reconsidered. In A. Gallego (ed.), Syntactic Variation in Spanish, 215-244. Oxford: Oxford University Press. https://doi.org/10.1093/oso/9780190634797.003.0008

Di Tullio, Ángela. 2005. Manual de gramática del Español. Buenos Aires: La isla de la luna.

Dufter, Andreas \& Stark, Elisabeth. 2008. Double indirect object marking in Spanish and Italian. In Elena Seoane \& María José López-Couso (eds.), Theoretical and empirical issues in grammaticalization, 111-129.

Amsterdam: John Benjamins. https://doi.org/10.1075/tsl.77.07duf

Enç, Mürvet. 1991. The semantics of specificity. Linguistic Inquiry 22, 1-26. 
Estigarribia, Bruno. 2006. Why clitic doubling? A functional analysis for Rioplatense Spanish. In T. L. Face \& C. A. Klee, (eds.) Selected Proceedings of the 8th Hispanic Linguistics Symposium, 123-136. Somerville, MA: Cascadilla Proceedings Project.

Fernández Soriano, Olga. 1999. El pronombre personal. Formas y distribuciones. Pronombres átonos y tónicos. In: I. Bosque \& V. Delmonte (eds.), Gramática Descriptiva de la Lengua Española, 1. Sintaxis Básica de las Clases de Palabras, 1209-1273. Madrid: Espasa. https://doi.org/10.4312/linguistica.41.1.176-178

Fontana, Josep M. 1993. Phrase structure and the syntax of clitics in the history of Spanish. Ph.D. Thesis, University of Pennsylvania.

Gabriel, Christoph. 2007. Fokus im Spannungsfeld von Phonologie und Syntax. Eine Studie zum Spanischen. Frankfurt: Vervuert. https://doi.org/10.31819/9783964561954

García-Miguel, José M. \& Vázquez, Victoria. 1994. Lingüística de corpus y lingüística descriptiva: el caso de la 'duplicación de objetos. Boletín de la Sociedad Española para el Procesamiento del Lenguaje Natural 14, 4762. https://doi.org/10.6035/e-tiit.2012.12

Gerlach, Birgit. 2002. Clitics between syntax and lexicon. Amsterdam: Benjamins.

Heusinger, Klaus v. \& Onea, Edgar. 2008. Triggering and blocking effects in the diachronic development of DOM in Romanian. Probus 20, 67-110. https://doi.org/10.1515/probus.2008.003

Hualde, José Ignacio. 2003. El modelo métrico y autosegmental. In: P. Prieto (ed.), Teorías de la entonación, 155-184. Barcelona: Editorial Ariel.

Jaeggli, Osvaldo. 1982. Topics in Romance syntax. Dordrecht: Foris.

Jaeggli, Osvaldo. 1993. Tres cuestiones en el estudio de los clíticos: El caso, los sintagmas nominales reduplicados y las extracciones. In O. Fernández Soriano (ed.), Los pronombres átonos, 141-173. Madrid: Espasa-Calpe. https://doi.org/10.3726/978-3-0351-0815-6/15

Johnson, Daniel E. 2009. Getting off the GoldVarb standard: Introducing Rbrul for mixed-effects variable rule analysis. Language and Linguistics Compass 3(1), 359-383. https://doi.org/10.1111/j.1749-818x.2008.00108.x

Jørgensen, Annette M. 2008. COLA: Un corpus Oral de Lenguaje Adolescente. Anejos a Oralia 3(1), 225-235.

Kayne, Richard. 1975. French syntax. The transformational cycle. Cambridge, Mass.: MIT Press.

Koch, Peter. 1993. Le 'chinook' roman face à l'empirie. Y a-t-il une conjugaison objective en français, en italien et en espagnol et une conjugaison subjective prédéterminante en français?. In Gerold Hilty (ed.), Actes $d u$ XXe Congrès International de Linguistique et Philologie Romanes, Université de Zurich (6-11 avril 1992), Bd. III, 169-190. Tübingen/Basel: Francke 1993. https://doi.org/10.1515/9783110923575.423 
Kuchenbrandt, Imme. 2007. Prosodische Aspekte in der Entwicklung der spanischen und französischen Klitika. $\mathrm{Ph}$. D. Thesis, University of Hamburg.

Labov, William. 1972. Sociolinguistic patterns. Philadelphia: University of Pennsylvania Press.

Leonetti, Manuel. 2007a. Sobre la relación entre doblado de clíticos y movimiento de objectos. Cuadernos de Lingüística del I. U. I. Ortega y Gasset 2007 (14), 135-152.

Leonetti, Manuel. 2007b. Clitics do not encode specificity. In G. Kaiser \& M. Leonetti (Eds.), Proceedings of the Workshop «Definiteness, Specificity and Animacy in Ibero-Romance Languages, 111-139. Arbeitspapiere des Fachbereichs Sprachwissenschaft der Universität Konstanz.

Leonetti, Manuel. 2008. Specificity in clitic doubling and in differential object marking. Probus 20(1), 33-66. https://doi.org/10.1515/probus.2008.002

Longobardi, Giuseppe. 1994. Reference and proper names: a theory of nmovement in syntax and logical form. Linguistic Inquiry 25(4), 609-665.

Mayer, Elisabeth. 2006. Optional direct object clitic doubling in Limeno Spanish. In: Miriam Butt \& Tracy Holloway King (eds.), International LexicalFunctional Grammar Conference (LFG 2006), p.18. Stanford, California: CSLI Publications.

Ormazabal, Javier, and Juan Romero. 2013. Object clitics, agreement and dialectal variation. Probus 25(2), 301-344. https://doi.org/10.1515/probus-2013-0012

Parodi, Teresa. 1998. Aspects of clitic doubling and clitic clusters in Spanish. In R. Fabri, A. Ortmann \& T. Parodi (eds.), Models of inflection, 85-102. Tübingen: Niemeyer. https://doi.org/10.1515/9783110919745.85

Pineda, Anna. 2013. Double object constructions in Spanish (and Catalan) revisited. In S. Baauw, F. Drijkoningen, L. Meroni \& M. Pinto (eds.), Romance languages and linguistic theory 2011, 193-216. Amsterdam/ Philadelphia: John Benjamins. https://doi.org/10.1075/rllt.5.10pin

Poston, Lawrence Jr. 1953. The redundant object pronoun in contemporary Spanish. Hispania 36(3), 263-272. https://doi.org/10.2307/335092

Pujalte, Mercedes, \& Saab, Andrés. 2018. Interacciones En El Filo Oracional Medrio. In Ignacio Bosque, Sylvia Costa \& Marisa Malcuori (eds.), Palabras en lluvia minuciosa. Veinte visitas a la gramática del español inspiradas por Ángela Di Tullio, 273-98. Madrid: Iberoamerica-Veurvert. (lingbuzz/003649) https://doi.org/10.31819/9783954877560

Pujalte, Mercedes, Saab, Andrés \& Zdrojewski, Pablo. 2017. Reflexiones en el filo: la sintaxis de los objetos doblados en el español rioplatense. Talk given in the III Jornadas de Jóvenes lingüistas, Instituto de Lingüística, Universidad de Buenos Aires. https://doi.org/10.14201/gredos.128856 
Roberts, Ian. 2011. Microparameters, Macroparameters \& Markedness. Talk held at the conference "Subjects in Diachrony" at the University of Regensburg 2011.

Saab, Andrés, \& Zdrojewski, Pablo. 2012. Anti-repair effects under ellipsis diagnosing (Post-) Syntactic Clitics in Spanish. In Andrés Saab, Irene Franco, \& Sara Lusini (eds.), Romance Languages and Linguistic Theory 2010: Selected Papers from 'Going Romance' Leiden 2010, 177-202. Amsterdam: John Benjamins Publishing. https://doi.org/10.1075/rllt.4.09saa

Saab, Andrés, \& Zdrojewski, Pablo. 2013. Dislocación y doblado pronominal en el español del Río de la Plata. In Ángela Di Tullio (ed.), El español de la Argentina: Estudios gramaticales, 131-151. Buenos Aires: EUDEBA. https://doi.org/10.31819/9783954871971-015

Sánchez, Liliana \& Zdrojewski, Pablo. 2013. Restricciones semánticas y pragmáticas al doblado de clíticos en el español de Buenos Aires y de Lima. Lingüística 29(2), 271-320. https://doi.org/10.11606/t.8.2019.tde-22112019-160543

Silva-Corvalán, Carmen. 1984. Semantic and pragmatic factors in syntactic change. In Jacek Fisiak (ed.), Historical syntax, 555-573. Berlin: Mouton. https://doi.org/10.1515/9783110824032.555

Suñer, Margarita. 1988. The role of agreement in clitic-doubled constructions. Natural Language and Linguistic Theory 6, 391-434. https://doi.org/10.1007/bf00133904

Tagliamonte, Sally A. 2006. Analysing sociolinguistic variation. Cambridge: Cambridge University Press.

Torrego, Esther. 1988. A DP analysis of Spanish nominals. Ms. University of Massachusetts.

Tsakali, Vina. 2008. "Double" floating quantifiers in Modern Greek and Pontic. In Sjef Barbiers, Olaf, Koeneman, Marika Lekaku, \& Margreet van der Ham (eds.), Syntax and semantics: Microvariation in syntactic doubling, Vol. 36, 189-204. Syntax and Semantics. England: Emerald. https://doi.org/10.1016/s0092-4563(08)36006-1

Uriagereka, Juan. 1988. On government. Ph.D. Thesis, University of Connecticut.

Zdrojewski, Pablo. 2008. ¿Por quién doblan los clíticos? Restricciones morfosintácticas sobre la duplicación pronominal en el español rioplatense. Master's Thesis, Universidad Nacional del Comahue. https://doi.org/10.31819/9783954871971-012

Zubizaretta, María Luisa. 1999. Las funciones informativas: tema y foco. In: Ignacio Bosque \& Violeta Demonte (eds.), Gramática descriptiva de la lengua española, Tomo 3, 4224-4240. Madrid: Espasa.

https://doi.org/10.4312/linguistica.41.1.176-178 